Boston University School of Law Scholarly Commons at Boston University School of Law

Faculty Scholarship

2002

\title{
From Monopolists to Markets?: A Political Economy of Issuer Choice in International Securities Regulation
}

Frederick Tung

Boston Univeristy School of Law

Follow this and additional works at: https://scholarship.law.bu.edu/faculty_scholarship

Part of the Securities Law Commons

\section{Recommended Citation}

Frederick Tung, From Monopolists to Markets?: A Political Economy of Issuer Choice in International Securities Regulation, 2002 Wisconsin Law Review 1363 (2002).

Available at: https://scholarship.law.bu.edu/faculty_scholarship/377 


\section{FROM MONOPOLISTS TO MARKETS?: A POLITICAL ECONOMY OF ISSUER CHOICE IN INTERNATIONAL SECURITIES REGULATION}

FREDERICK TUNG ${ }^{*}$

Introduction 1364

I. Background: The Current Territorial System and Issuer

Choice Proposals 1370

A. National Regulation, International Transactions

1. Securities Act Registration and Regulation S

2. Harmonization Efforts

B. Issuer Choice

1. Romano's Proposal

2. "Portable Reciprocity” of Choi \& Guzman........................ 1381

3. Assumed Incentives of Regulators .................................... 1382

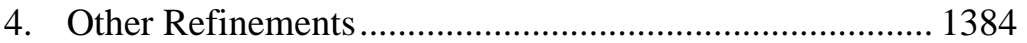

C. Who Will Supply Choice of Law Rules? .................................. 1386

D. Corporate Charter Competition in the United States................ 1390

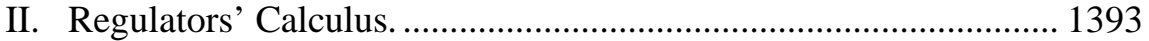

A. Regulatory Monopoly and Regulation as Price....................... 1395

B. Regulatory Monopoly and Regulatory

Price Discrimination

1. Conditions for Price Discrimination.................................. 1399

2. Price Discrimination in the United States.......................... 1401

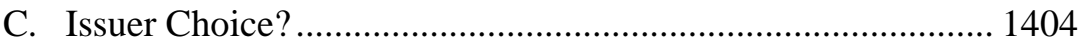

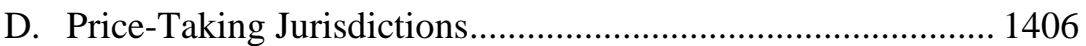

III. Interest Groups and International Cooperation................................. 1407

A. Regulators' Dominant Role in International

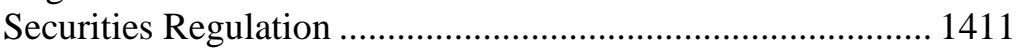

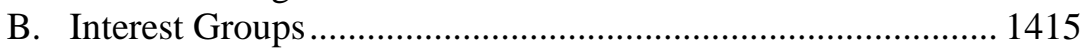

1. Lawyers and Accountants.............................................. 1416

2. Exchanges and Securities Firms ...................................... 1420

3. Issuers and Investors........................................................ 1423

* Professor of Law, University of San Francisco School of Law. A.B. 1983, Cornell; J.D. 1987, Harvard Law School. E-mail: tungf@usfca.edu; web: http://www.usfca.edu/law/tung. This Article benefited from comments and suggestions by Steve Bainbridge, Stephen Choi, Jim Cox, Jill Fisch, David Franklyn, Andrew Guzman, Alice Kaswan, Alan Meese, Roberta Romano, Bill Wang, participants at a meeting of the AALS Section on Securities Regulation (2002), and participants at faculty workshops at the University of Virginia School of Law, Loyola Law School, the University of Cincinnati College of Law, and the University of San Francisco School of Law. 
C. The Calculus of International Consent

1. International Coalitions and Dispersed Veto Power

2. Complexity of an International Issuer Choice Theory ....... 1428

D. Alternative Ending: Harmonization?

IV. Conclusion.

"Like many businessmen of genius he learned that free competition was wasteful, monopoly efficient. And so he simply set about achieving that efficient monopoly."

\section{INTRODUCTION}

Investors, employees, and regulators are still reeling from the recent spectacular accounting improprieties committed by the largest of U.S. corporations. Fraud and scandal at Enron Corporation ${ }^{2}$ and WorldCom, Inc. ${ }^{3}$ drove them each into bankruptcy less than eight months apart. At

1. Mario PuZo, The Godfather 213 (Signet 1978) (1969).

2. On December 2, 2001, Enron Corporation, the once-multibillion dollar energy company and strident advocate for energy deregulation, hobbled into bankruptcy after having made a series of startling disclosures concerning financial misreporting and serious conflicts of interest. On October 16, 2001, the company announced a \$1 billion charge against its third-quarter earnings to correct for other accounting errors related to the financing of affiliated entities. The next day, the Wall Street Journal reported that \$35 million of Enron's losses related to its dealings with two partnerships run by its chief financial officer, Andrew Fastow. See Kurt Eichenwald with Diana B. Henriques, Enron Buffed Image to a Shine Even as It Rotted From Within, N.Y. TIMES, Feb. 10, 2002, at A1. In November, the firm announced that it had overstated earnings from 1997 forward by \$586 million, a reporting error due primarily to improper accounting for its dealings with affiliated entities. A corrected restatement of its earnings reduced profits for the period by twenty percent. See John R. Emshwiller et al., Enron Slashes Profits Since 1997 by 20\%, WALl ST. J., Nov. 9, 2001, at A3. In fact, for months Enron had been hiding hundreds of millions of dollars in losses by stashing them on the books of nominally independent affiliated entities. A substantial portion of its profits over a four-year period were apparently generated through accounting manipulations. See SPECIAL INVESTIGATION COMM. OF THE BD. OF DiRs. OF ENRON CORP., REPORT OF InVESTIGATION (Feb. 1, 2002).

At its peak stock price near $\$ 90$ per share in August 2000, Enron was America's seventh largest corporation by market capitalization. William W. Bratton, Does Corporate Law Protect the Interests of Shareholders and Other Stakeholders?: Enron and the Dark Side of Shareholder Value, 76 Tulane L. REV. 1275, 1276 (2002). By the time of Enron's bankruptcy, investors in the company had seen $\$ 63$ billion in market value wiped out in less than a year. See Peter Coy et al., Enron: Running on Empty, Bus. WK., Dec. 10, 2001, at 80. Enron employees were among those unfortunate investors. At the end of 2000, their company pension plan held $\$ 2.1$ billion in assets, of which $\$ 1.3$ billion consisted of Enron stock. That stock is now worthless. See Theo Francis \& Ellen Schultz, Enron Faces Suits by 401(k) Plan Participants, WALl ST. J., Nov. 23, 2001, at C1.

3. On July 21, 2002, telecommunications giant WorldCom, Inc. filed for bankruptcy on the heels of the company's announcement that it had "misstated" 
the time of their respective filings, each enjoyed the dubious honor of being the largest bankruptcy filing in history. ${ }^{4}$ Responding to these and other illegalities, the Securities and Exchange Commission (SEC), the Department of Justice, numerous Congressional committees, and the New York State Attorney General's Office all launched investigations. The New York Stock Exchange (NYSE) formed a Corporate Accountability and Listing Standards Committee to recommend corporate governance reform. ${ }^{5}$ Corporate officers have been indicted for securities fraud. ${ }^{6}$ Numerous civil suits have been filed on behalf of investors. ${ }^{7}$ And Congress and the NYSE have imposed far reaching new corporate governance and accountability rules on public companies. ${ }^{8}$ Other nations

expenses-and thus overstated profits-in 2001 and the first quarter of 2002 by $\$ 3.85$ billion. Later disclosures admitted that for a period from 1999 through 2002, the firm had overstated profits by at least $\$ 7.2$ billion, a figure that likely makes it the largest accounting fraud in history. Jared Sandberg \& Susan Pulliam, WorldCom Revision Might Double, WALL ST. J., Aug. 9, 2002, at A3. In addition, its former CEO borrowed $\$ 400$ million from the company before he was ousted, a sum he still owes. Steven Rosenbush et al., Inside the Telecom Game: How a Small Group of Insiders Made Billions as the Industry Collapsed, Bus. WK., Aug. 5, 2002, at 34.

4. Shawn Young et al., WorldCom Files for Bankruptcy, Wall ST. J., Jul. 22, 2002, at A3; Wendy Zellner et al., The Fall of Enron, Bus. WK., Dec. 17, 2001, at 33. In its filing, WorldCom listed $\$ 107$ billion in assets, while Enron's filing involved a "mere” $\$ 63.4$ billion in assets. Young, supra, at A3.

5. See generally N.Y. StOCK EXCH., YOUR Market: StRAight TAlK FOR INVESTORS (July 2002).

6. See Jerry Markon \& Jared Sandberg, Ex-WorldCom Officials Are Indicted, Wall ST. J., Aug. 2, 2002, at A3.

7. See, e.g., Francis \& Schultz, supra note 2; New York Fund to Lead WorldCom Lawsuit, Wall ST. J., Aug. 13, 2002, at B4.

8. Congress passed the Sarbanes-Oxley Act, the most sweeping corporate regulatory statute since the Great Depression. See Public Company Accounting Reform and Investor Protection Act of 2002, Pub. L. No. 107-204, 116 Stat. 745 (codified as amended in scattered sections of 11, 15, 18, 28, 29 U.S.C.). Among other things, the Act imposes requirements as to (i) officer certification of firms' annual and quarterly reports, see id. 15 U.S.C. $\S 7241$, (ii) the composition and function of corporate boards' audit committees, see id. § 78j-1, and (iii) the independence of outside auditors, see id. §§ 78c, 78g, 78j-1, 78l. The Act also establishes a Public Company Accounting Oversight Board to oversee outside auditors of public companies, see id. $\S \S 77 \mathrm{~s}, 78 \mathrm{~m}, 7211-7219$, and creates new criminal offenses and raises penalties for some existing offenses, see id. $\S \S 7242,7244$. Proposed NYSE rules impose requirements as to director independence and the composition, function, and authority of non-management directors and boards' audit compensation, and nominating/governance committees. Each listed company must adopt and disclose corporate governance guidelines and a code of business conduct and ethics. The new rules also require shareholder approval of almost all stock option plans. See NYSE, Corporate Governance Rule Proposals Reflecting Recommendations CommitTeE as Approved by the NYSE BoARD of DireCtors, August 1, 2002, available at http://www.nyse.com/pdfs/corp_gov_pro_b.pdf. The proposed rules are subject to SEC approval and are expected to be approved. See Kip Betz, NYSE Board Approves Changes 
as well, searching for models of transparency and accountability for their securities laws, have reconsidered their earlier embrace of the U.S. example. ${ }^{9}$

It is ironic that during this period of corporate scandal and regulatory soul searching, one of the most spirited debates among corporate and securities law scholars has focused on reform proposals for international securities regulation that essentially call for corporate self-regulation. According to these proposals - one by Roberta Romano of Yale Law School, ${ }^{10}$ and the other by Stephen Choi and Andrew Guzman at Boalt Hall $^{11}$-an issuer of securities should be allowed to choose the regime of securities regulation that will govern it, and all nations would commit to respecting each firm's particular choice of securities law. Each firm would be allowed to select the securities regulatory regime of any country, and have that chosen regulation govern the firm's securities activities in every country. ${ }^{12}$ Given the choice, the argument goes, each issuer would pick the regulatory regime that offers the optimal level of regulation for itself and its investors. Proponents assert, therefore, that this "issuer choice" approach achieves efficient securities regulation on a global basis.

Existing regulation and regulatory practice in the world are inefficient, according to issuer choice advocates. As currently structured, securities regulation is territorial. That is, each nation claims exclusive jurisdiction to regulate securities transactions that occur within its borders. This is problematic for issuer choice proponents. Because each national regulator insists on exclusivity in regulating the offering, selling, and trading of securities within its national borders, territoriality effectively grants each regulator a national "monopoly" on regulation. As monopolists, regulators have insufficient incentive to offer efficient

to Corporate Governance Listing Standards, 34 Sec. Reg. \& L. Rep. 1269 (BNA) (Aug. 5, 2002).

9. See A Whiff of Impropriety: Corporate Wrongdoing in Japan, THE ECONOMIST, Aug. 3, 2002, at 54-55 (discussing Japanese accounting reform efforts).

10. See Roberta Romano, Empowering Investors: A Market Approach to Securities Regulation, 107 YALE L.J. 2359 (1998) [hereinafter Romano, Empowering Investors]; Roberta Romano, The Need for Competition in International Securities Regulation, 2 ThEORETICAL INQUIRIES L. 387 (2001) [hereinafter Romano, Need for Competition]. Romano has recently published a book-length treatment of her proposal. See Roberta Romano, The Advantage of Competitive Federalism in Securities REGULATION (2002).

11. See Stephen J. Choi \& Andrew T. Guzman, Portable Reciprocity: Rethinking the International Reach of Securities Regulation, 71 S. CAL. L. REV. 903 (1998)

12. This is tantamount to self-regulation since presumably a country exists that would oblige the regulatory desires of any firm willing to pay an appropriate fee. International tax, banking, and bankruptcy havens provide useful analogies. See infra note 17 and accompanying text. 
rules - the rules that issuers and investors would prefer. ${ }^{13}$ Instead, national regulators are free to benefit themselves and favored constituents through their rulemaking, ${ }^{14}$ at the expense of issuers and investors.

The issuer choice antidote to this curse of regulatory monopoly is, of course, competition. In effect, proponents of issuer choice call for the creation of an international market in securities regulation. In this market, regulation itself is the product, one that nations would "sell" and firms and investors would "buy." National regulators and other law givers in each nation would "supply" securities regulation in this market. And the consumers of securities laws, of course, are issuers and investors. Free to choose their securities laws, they would make up the market "demand."15 With firms free to choose their law, national regulators would be forced to compete to supply desirable regulation.

Not surprisingly, the issuer choice idea has sparked a spirited debate among scholars, and has even captured the attention of the popular press. ${ }^{16}$ Under issuer choice, securities law should never be mandatory but should be a matter for firms' private choice. Issuers may choose any regulation or no regulation, ${ }^{17}$ and while issuer choice advocates express confidence that market forces will prod most issuers to submit to nontrivial regulation, policy makers throughout the world would have to be prepared to honor an issuer's choice of "no regulation."18

To date, the primary challenge to issuer choice has been that it will not "work" as predicted. Scholars have focused primarily on the demand side of the market for regulation-questioning whether the behavior of firms and investors would truly create a demand for efficient law. Merritt Fox doubts that firm managers have the right incentives to choose optimal regulation, ${ }^{19}$ and Jim Cox has questioned whether investors in the market

13. Another problem for Choi \& Guzman is that some nations, like the United States, may sometimes extend the reach of their laws to apply extraterritorially. This may raise concerns over conflicts with other nations' laws. See Stephen J. Choi \& Andrew T. Guzman, The Dangerous Extraterritoriality of American Securities Law, 17 Nw. J. INT'L L. \& Bus. 207 (1996).

14. This private interest view of regulatory behavior is a fairly standard perspective in the public choice literature. See infra Part I.B.3.

15. A firm's managers would select the regulatory regime applicable to the firm, and investors would choose the firms in which they prefer to invest, presumably taking account of each firm's chosen regulatory regime.

16. See The Market for Regulation, THE ECONOMIST, Mar. 7, 1998, at 82.

17. Choi has made this point explicitly. See Stephen J. Choi, Promoting Issuer Choice in Securities Regulation, 41 VA. J. INT'L L. 815, 816 (2001).

18. With issuer choice, Enron and WorldCom, for example, could have avoided indictments, lawsuits, and investigations had they simply elected to be governed by a regulatory regime compatible with the creative accounting they each practiced.

19. See Merritt B. Fox, The Issuer Choice Debate, 2 TheORETICAL INQUIRIES L. 563, 564 (2001) [hereinafter Fox, The Issuer Choice Debate]; Merritt B. Fox, The 
can efficiently price differences in regulatory regimes. ${ }^{20}$ By contrast, this Article focuses on a different question: not on whether issuer choice would work but on whether it would ever happen. This important question has yet to be explored in the scholarly literature. My claim is that issuer choice is politically implausible. I examine the supply side of the market for securities regulation, focusing on choice of law rules and the incentives of political actors to supply them. I argue that given the stated assumptions of issuer choice advocates, issuer choice is very unlikely ever to come about.

For the issuer choice model to work, national regulators must supply two different types of rules-not only substantive securities regulation, but choice of law rules as well. In particular, each nation would have to forswear its customary territorial jurisdiction over securities activity that occurs within its borders. Instead, it would have to agree that for each firm engaging in securities activity within its territory, it would apply the securities law that the firm had selected. While analysts on all sides have discussed the dynamics of competition over substantive rules, they have ignored the fact that competition over substantive rules requires cooperation among nations in structuring the international market in which the various nations would compete over substantive rules. This requires that states agree on a choice of law rule honoring firm choice.

But there is a problem. Issuer choice proposals rely critically on standard public choice assumptions about the incentives and motivations of political actors. ${ }^{21}$ Under these assumptions, regulators in general desire to aggrandize their bureaucracies, and with securities regulation, they do this by maximizing the number of firms and transactions under their regulatory purview. For issuer choice, this explains why regulators would compete to offer desirable securities law if firms were free to choose their own laws. Each national regulator would wish to maximize the number of firms adopting her laws in order to enhance the scope and importance of her bureaucracy.

On these assumptions, however, it is difficult to see how the appropriate choice of law rules could emerge, or how international agreement on them could be reached. In a word, we can't get there from here. The very incentives that would theoretically drive national

Political Economy of Statutory Reach: U.S. Disclosure Rules in a Globalizing Market for Securities, 97 Mich. L. REV. 696, 749 (1998) [hereinafter Fox, Political Economy]; Merritt B. Fox, Retaining Mandatory Securities Disclosure: Why Issuer Choice Is Not Investor Empowerment, 85 VA. L. REV. 1335, 1345 (1999) [hereinafter Fox, Retaining Mandatory Securities Disclosure]; see also infra note 95 and accompanying text.

20. See James D. Cox, Regulatory Duopoly in U.S. Securities Markets, 99 Colum. L. REV. 1200, 1234 (1999); see also infra text accompanying note 96.

21. See infra Part I.B.3. 
regulators to compete, if an international market for regulation existed, would also make them unwilling to supply the choice of law rules essential to creating that market in the first place, at least in important jurisdictions. Regulators with cozy regulatory monopolies, intent on aggrandizing their bureaucracies, would oppose competition. They would not agree to respect firms' private choice of securities regulation, since that would expose their bureaucracies to challenge. Rather than surrendering their national monopolies, they would instead fight to preserve their protected markets.

I also consider the possibility that other national lawmakerslegislators and executives - could supply the requisite choice of law rules for issuer choice. But I ultimately discount that possibility. Informational advantages will enable regulators to play a dominant role in formulating policy on international securities regulation, making it difficult for legislators or executives to initiate fundamental reform that regulators oppose. In addition, interest groups in important jurisdictions will not support issuer choice, making it even less likely that legislators or executives would take up the cause. For argument's sake, I remain true to the public choice assumptions adopted by issuer choice advocates in order to show the difficulty of telling a consistent issuer choice story that includes the necessary choice of law rules. A public choice approach suggests a move not toward issuer choice, but toward "regulatory price discrimination" by important jurisdictions, as well as possible efforts toward increased international harmonization. I rely primarily on examples from U.S. law in my analysis, generalizing to other countries where appropriate.

Part I of the Article provides background. It discusses the strains placed on national regulatory regimes by global securities markets, and it describes the main issuer choice proposals. Part II discusses regulators' calculus in the face of issuers' and investors' increasing international mobility. It describes the opportunities and constraints of regulators in different types of jurisdictions in terms of pursuing their private interests. In "price-setting jurisdictions," regulators will pursue regulatory price discrimination, not issuer choice. Part III examines the probable influences of interest groups on the prospects for achieving the international choice of law cooperation required for issuer choice. It argues that regulators will dominate legislators and executives in setting policy on international securities regulation, and that no interest group would unambiguously support issuer choice. Part IV concludes.

\section{BACKGROUND: THE CURRENT TERRITORIAL SYSTEM AND ISSUER CHOICE PROPOSALS}

In this Part, I begin by describing the territorial system that currently prevails in the world and efforts by regulators to adapt national regulation 
to the global securities market. With the increasing international mobility of issuers and investors, it becomes more and more common that activities in one country may affect securities markets in others. In the face of this phenomenon, national regulators may have difficulty enforcing their national laws or protecting their national markets from effects that originate abroad. I describe two different adaptive approaches - extraterritoriality and harmonization - that aim to assure the effectiveness of national regulation. U.S. law illustrates regulators' extraterritorial tendency. It shows a tension between nominal territoriality and national regulators' temptation to extend their reach-regulating transactions with fairly weak connections to their domestic securities markets - in order to assure the effectiveness of their national laws. This extraterritorial tendency may lead to conflicts of law, as national regulatory systems overlap in their regulatory efforts.

Harmonization, the second approach, involves nations' attempts to align substantive policies and cross-border enforcement efforts. Through this coordinated approach, national regulators hope to vindicate national policies and prevent their easy circumvention by actors that might otherwise seek out lax jurisdictions in which to conduct securities activities. $^{22}$

Issuer choice advocates condemn both these approaches as mere attempts by regulators to extend the reach of their territorial monopolies. After describing this uneasy fit between national regulation and international transactions, I sketch the issuer choice approach as proposed separately by Romano ${ }^{23}$ and Choi and Guzman. ${ }^{24}$ While distinctive in the details, the central argument in both proposals is that issuers should be allowed to choose the regime of securities regulation under which they will be governed worldwide. I then introduce the problem of choice of law cooperation, which would be necessary to create the international market for securities regulation envisioned by issuer choice proponents.

22. For example, when a company lists its securities for trading on multiple exchanges in different countries, prohibitions against insider trading in one country can easily be circumvented by trading on the exchange of another country that has not adopted or does not enforce the same prohibitions.

23. See Romano, Empowering Investors, supra note 10, at 388-89; Romano, Need for Competition, supra note 10, at 2361-62.

24. See Choi \& Guzman, supra note 11 , at 907. 


\section{A. National Regulation, International Transactions}

As with most laws, the reach of securities law is nominally territorial. ${ }^{25}$ A nation typically applies its securities laws to securities transactions that occur within its borders, or that have substantial effects within its territory. ${ }^{26}$ For example, in the United States, every issuer that lists its securities for trading on the NYSE is required to register under Section 12(a) of the Securities Exchange Act of 1934 (Exchange Act) ${ }^{27}$ and becomes subject to periodic disclosure and reporting requirements under that statute. ${ }^{28}$ This requirement applies whether the issuer is a foreign corporation or a domestic one. On the other hand, a U.S. issuer engaging in a public offering of its securities abroad must generally comply with the laws of the jurisdiction in which the offering is made, but provided certain conditions are met, ${ }^{29}$ the issuer is not required to comply with the registration requirements of the Securities Act of 1933 (Securities Act), which regulates public offerings in the United States. ${ }^{30}$

If each nation regulates only territorially, then at least conceptually, conflicts of law can be avoided. With securities regulation, though, as in many other areas, the conceptual tidiness of this territorial principle has been rendered illusory. It has been strained by the ever-increasing volume of cross-border securities offerings and trading. A Japanese investor purchasing shares of a Dutch company listed on the NYSE, for instance, is routine. Technological progress has made investors and issuers increasingly more mobile. Firms can readily offer and sell, and

25. See Restatement (ThiRd) OF Foreign Relations LAW § 402 (1987) (describing bases of prescriptive jurisdiction). "Territoriality is considered the normal . . . basis for the exercise of jurisdiction.” Id. § $402 \mathrm{cmt}$. b.

26. The Restatement views the effects principle as an aspect of territoriality, while recognizing that it is sometimes considered a distinct category. See id. § $402 \mathrm{cmt}$. d.

27. 15 U.S.C. \& 78l(a) (2000).

28. See id. $\S 78 \mathrm{~m}(\mathrm{a})-(\mathrm{h})$. The Exchange Act is the primary legislation relating to regulation of national securities exchanges, among other things.

Daimler Benz felt the sting of U.S. reporting requirements when it decided to list its shares on the NYSE in 1993. See Cox, supra note 20, at 1203. Daimler's shares had been listed only in Germany before 1993. See id. One nagging requirement for the firm in listing in the United States and reporting under U.S. securities laws was the requirement to reconcile its books to U.S. generally accepted accounting principles (GAAP). See id. U.S. GAAP accounting made transparent Daimler's practice, under more liberal German accounting rules, of smoothing out earnings from year to year by in effect hiding earnings as "reserves" in the more profitable years, and then drawing on those reserves in less profitable years to boost earnings in those leaner years. See id. The contrasting results of these accounting rules were made clear in the very first year of Daimler's U.S. listing, when it reported a \$354 million profit under German accounting standards, but a loss of \$1 billion under U.S. GAAP. See id.

29. See Regulation S Rules 901-905, 17 C.F.R. §£ 230.901-.905 (2002).

30. See 15 U.S.C. §§ 77a-77bbbb (2000). 
investors can readily buy and trade, securities outside their home countries. But which countries' laws should or should not apply to these cross-border transactions is not always clear. When conduct in one country affects investors in another-say a fraudulent scheme is perpetrated through the conduct of actors in several countries and causes losses in yet another country-several nations may justifiably assert the application of their national securities laws. Conflicts will arise. Choice of law rules-allocating regulatory authority among sovereigns-become critical. ${ }^{31}$ However, international efforts to coordinate securities regulatory jurisdiction have been few and frustrating. ${ }^{32}$ Without clear choice of law, conflicting assertions of territorial jurisdiction subject transactions to multiple overlapping regulatory regimes, which may create conflicting legal obligations, deter desirable transactions, and cause tension among sovereigns. ${ }^{33}$ Scholars and policymakers are having to face the question squarely: what should be the appropriate relationship among national regulatory regimes?

Policymakers may have difficulty devising a simple or straightforward answer, as U.S. law illustrates. U.S. securities law is basically territorial. However, in certain areas, specific rules and doctrines rely to some extent on extraterritorial reach in order to safeguard U.S. investors or the U.S. market from harm. U.S. law might therefore apply to predominantly foreign transactions, when exclusive application of other countries' laws might be more appropriate. I discuss one example below: the Securities Act registration requirement and Regulation S, which addresses offshore public offerings. Regulation S illustrates the strain of attempting to apply territorial regulation to global securities markets and the temptation to extraterritorial reach. In addition, I briefly discuss one increasingly popular approach to international regulatory coordination: harmonization of regulatory standards among national securities regimes and the SEC's efforts in that regard.

31. As implied above, the focus here is primarily on prescriptive jurisdictionjurisdiction to prescribe applicable rules - and not on judicial or other enforcement jurisdiction. See Restatement (THIRD) OF FOREIGN RELATIONS LAW § 402 (discussing prescriptive jurisdiction).

32. Even within the European Union (EU), which has steadfastly pursued regulatory coordination for decades, the results have not been encouraging. See Howell E. Jackson \& Eric J. Pan, Regulatory Competition in International Securities Markets: Evidence from Europe in 1999-Part I, 56 Bus. LAw. 653, 676 (2001). Through its Public Offers Directive, for example, the EU attempted to create a "regulatory passport" system to enable issuers to make public offerings of securities throughout the EU relying only on their home country offering documents. See id. at 680. However, largely because of local regulatory protectionism, the Public Offers Directive is not useful and has had virtually no impact on public offerings within the EU. See id. at 680-81.

33. See generally Andrew T. Guzman, Choice of Law: New Foundations, 90 GEO. L.J. 883 (2002). 


\section{SECURITIES ACT REGISTRATION AND REGULATION S}

For public offers and sales of securities, registration is generally required under the Securities Act. $^{34}$ Section 5, the cornerstone for regulation of primary transactions in the United States, ${ }^{35}$ sets out the basic registration requirement. Registration requires the production of an extensive and complex disclosure document - the registration statementmeant to provide adequate information to enable investors to make their investment decisions. ${ }^{36}$ The registration statement must be filed with the SEC before offers to buy or sell a security may be made. ${ }^{37}$ In addition, the registration statement must be declared effective before any sale or delivery of securities may occur. ${ }^{38}$

Through its promulgation of Regulation $\mathrm{S},{ }^{39}$ the SEC sought to clarify application of the registration requirement to offshore offerings. In terms of extraterritorial reach, Section 5 nominally applies to all offers and sales of securities that "make use of any means or instruments of transportation or communication in interstate commerce." 40 Interstate commerce is defined quite broadly to include "trade or commerce in securities or any transportation or communication relating thereto ... between any foreign country and any State, Territory, or the District of Columbia." 41

Read literally, this definition of interstate commerce could extend the reach of Section 5 to offerings by U.S. issuers made completely outside the United States to foreign investors. Historically, however, the SEC has never applied it so broadly. When questions of extraterritorial reach first arose in the 1960s, the SEC articulated its view that registration was meant primarily to protect U.S. investors. Therefore, registration would not be required for offerings by U.S. issuers "made under circumstances

34. Numerous exemptions exist. See Thomas lee Hazen, The LaW of SECURITIEs Regulation, at ch. 4 (4th ed. 2002).

35. See 15 U.S.C. $\S 77$ e.

36. See id.

37. See id. $\S 77 \mathrm{e}(\mathrm{c})$.

38. See id. § 77e(a)(1).

39. See Regulation S Rules 901-905; 17 C.F.R. §§ 230.901-.905; see also Offshore Offers and Sales, Securities Act Release No. 6863, [1989-1990 Transfer Binder] Fed. Sec. L. Rep. (CCH) I 84,524 at 80,661 (April 24, 1990) [hereinafter Regulation S Initial Release]; Offshore Offers and Sales (Regulation S), Securities Act Release No. 7505, Fed. Sec. L. Rep. (CCH) ๆ 86,006, at 80,156 (Feb. 17, 1998) (amending Release No. 6863).

40. $\quad 15$ U.S.C. $\S 77 e(a)(1)$.

41. Id. $\S 77 \mathrm{~b}(7)$. 
reasonably designed to preclude distribution or redistribution of the securities within, or to nationals of, the United States."

Regulation S, promulgated in 1990 in order to clarify then-existing policy, declared the SEC's explicit embrace of a territorial approach to Securities Act registration. ${ }^{43}$ Regulation $\mathrm{S}$ provides safe harbors for offers and sales of securities "outside the United States," 44 so that registration is not required. ${ }^{45}$ "The territorial approach recognizes the primacy of the laws in which a market is located. As investors choose their markets, they choose the laws and regulations applicable in such markets." ${ }^{46}$ This approach marked a shift from protecting U.S. investors generally to protecting "the U.S. capital markets and investors purchasing in the U.S. market, whether U.S. or foreign nationals."

The Regulation S rules, however, may have extraterritorial effects that belie their proclaimed territorial aspiration. In particular, the regulation includes restrictions designed to prevent resale into the United States of securities initially offered abroad, or "flowback." 48 These flowback restrictions may directly affect wholly foreign transactions, even though Regulation S was ostensibly meant to track a strictly territorial design.

The basic definitions are not problematic. An issuer's offer or sale of securities is deemed "outside the United States" if:

(a) it is made only to persons outside the U.S.;

(b) either

(i) the purchasers are reasonably believed to be outside the U.S. when they originate their purchase orders, or (ii) the transactions are executed on an established foreign securities exchange; and

(c) there are no direct selling efforts in the United States. ${ }^{49}$

42. Marc I. Steinberg, International Securities Law: A Contemporary AND Comparative ANALYSIS 183 (1999) (quoting Securities Act Release No. 4708 (July 1964)). Through an initial release and subsequent no-action letters, the SEC crafted a policy attempting to assure that securities issued offshore by U.S. issuers came to rest abroad and did not flow back to the United States or to U.S. nationals. Id.

43. See Regulation S Initial Release, supra note 39, at 80,665. See also Choi \& Guzman, supra note 13, at 210.

44. Regulation S Initial Release, supra note 39, at 80,665.

45. For discussions of the background and requirements of Regulation S, see Fox, Political Economy, supra note 19, at 708 and Choi \& Guzman, supra note 13, at 210.

46. See Regulation S Initial Release, supra note 39, at 80,665.

47. Id.

48. Id.

49. 17 C.F.R. $\S \S 230.902(h), 230.903(a)$. 
However, depending on the type of securities involved, additional restrictions aimed at preventing flowback into the United States may deter wholly foreign transactions and interfere with other nations' securities markets. ${ }^{50}$ Offshore equity offerings by U.S. issuers, for example, may not include offers or sales to U.S. persons for one year, ${ }^{51}$ even if those investors signal their willingness to forego U.S. regulatory supervision by purchasing outside the United States. In addition, non-U.S. residents purchasing from the issuer must expressly agree to sell only to other nonU.S. purchasers, who agree to similar restrictions during the one-year period, and so on. ${ }^{52}$ Not only do these transfer restrictions circumscribe the ability of U.S. purchasers to opt out of U.S. regulation, as was originally advertised with Regulation $S,^{53}$ but they effectively preclude issuers from listing shares issued under Regulation $S$ for trading on a foreign exchange, since compliance with Regulation $S$ would be made impossible. ${ }^{54}$ But the inability to list the shares makes them illiquid and therefore relatively unattractive, drastically reducing the utility of Regulation S equity offerings for U.S. issuers. ${ }^{55}$

50. Id. § 230.903(b).

51. See 17 C.F.R. $\S 230.903(b)(3)(i i i)$. This one-year period is referred to as the “distribution compliance period.” Id. § 230.902(f). A “U.S. person” includes individuals resident in the United States, partnerships and corporations organized under U.S. laws, and trusts of which any trustee is a U.S. person. Id. § 230.902(k)(1).

52. See id. § 230.903(b)(3)(iii); see also Hal S. Scott, Internationalization of Primary Public Securities Markets, 63 LAW \& Contemp. Probs. 71, 95 (2000) (describing restriction on reselling to U.S. persons during distribution compliance period). Equity securities of domestic issuers are also "restricted securities" under Rule 144. 17 C.F.R. §§ 230.144, 230.905. Resale into the United States of such Regulation S securities may therefore also be subject to Rule 144 restrictions.

53. See supra note 46 and accompanying text.

54. In an impersonal, faceless stock exchange transaction, it would be practically impossible for a seller to prescreen purchasers based on their country of residence or to impose transfer restrictions as part of the transaction.

55. See Fox, Political Economy, supra note 19, at 710 \& n.33. Practical application of Regulation S and Exchange Act registration rules to U.S. issuers also makes it highly unlikely that even a U.S. firm that publicly offers shares only abroad could avoid U.S. disclosure rules. Even if a U.S. issuer made its Regulation S share offering and successfully avoided Securities Act registration, it is highly unlikely to be able to avoid Exchange Act registration and the concomitant disclosure obligations. Section 12(g)(1) and Rule $12 \mathrm{~g}-1$ of the Exchange Act together require registration by any issuer with $\$ 10$ million in assets and more than 500 shareholders of record. See 15 U.S.C. § 78l(g)(1) (2000); 17 C.F.R. $\S 240.12$ g-1 (2002). For the U.S. issuer, whether its shareholders are foreign or domestic does not affect this registration requirement, which also triggers mandatory disclosure very similar to that mandated under the Securities Act for public offerings. See Fox, Political Economy, supra note 19, at 715 \& n.47. The issuer's reincorporation under the laws of a foreign country may make it marginally easier to avoid U.S. regulation. 
Regulation S transfer restrictions may be necessary to prevent flowback and the dangers to U.S. investors of trading in unregistered securities. ${ }^{56}$ However, the restrictions significantly affect securities activity in other nations as well. Fear of flowback prevents U.S. investors from purchasing U.S. issuers' equity offerings abroad, despite these investors' apparent willingness to live with the regulatory protections of a foreign jurisdiction. Flowback concerns also preclude for a period the foreign listing of U.S. issuers' shares, at the peril of having to comply with U.S. registration requirements! Regulation $\mathrm{S}$ thus has a significant impact on the possibilities for offshore equity offerings by U.S. issuers, even though under a territorial approach, the foreign jurisdiction's regulation would generally be expected to play the primary role in setting the terms for offerings and listings within its borders. No doubt the risk of these U.S. securities finding their way back to the United States is a real one. However, the extraterritorial consequences of these rules also illustrate the difficulty of structuring putatively territorial regulation within neat territorial lines.

Commentators have criticized U.S. extraterritoriality from different quarters. Not surprisingly, issuer choice advocates believe that U.S. law overregulates to begin with, and that expanding its international reach merely compounds the problem by impeding capital mobility and easy exit by investors. ${ }^{57}$

\section{HARMONIZATION EFFORTS}

In addition to some creeping extraterritoriality in U.S. law, the SEC and other national securities regulators have responded to international securities activities with attempts at harmonizing substantive standards and increasing cooperation in terms of information sharing and enforcement. The SEC has taken a leading role in these endeavors. It has

A U.S.-listed foreign issuer may also find its wholly foreign offering subjected to annoying restrictions. For instance, if the foreign offering is made in two or more countries and there is "substantial U.S. market interest" in the security, not only are sales to U.S. persons precluded for forty days, but the issuer's underwriter and other distributors must agree in writing that offers and sales will not run afoul of U.S. registration requirements, and all offering materials must state that the securities have not been registered under the Securities Act and may not be offered or sold in the United States or to U.S. persons, absent registration or an available exemption. See 17 C.F.R. § 230.903(b) (2002).

56. See Problematic Practices Under Regulation S, Exchange Act Release No. 33-7190, 60 Fed. Reg. 35,663 (July 10, 1995); Josh Futterman, Note, Evasion and Flowback in the Regulation S Era: Strengthening U.S. Investor Protection While Promoting U.S. Corporate Offshore Offerings, 18 FORDHAM INT’L L.J. 806 (1995).

57. See Romano, Empowering Investors, supra note 10, at 2362; Choi \& Guzman, supra note 13. 
been a leading proponent of harmonization through its participation in the International Organization of Securities Commissions (IOSCO), ${ }^{58}$ pushing other nations to adopt disclosure and accounting standards, insider trading prohibitions, and other rules comparable to those of the United States. ${ }^{59}$ In addition, the SEC has executed Memoranda of Understanding with several dozen countries in order to facilitate information sharing in furtherance of extraterritorial enforcement of their respective domestic securities laws. ${ }^{60}$

The SEC approach implies that all nations should adopt high regulatory standards similar to those operating in the United States. With greater international harmonization toward U.S. standards, issuers and investors would have more difficulty fleeing to lax jurisdictions to conduct their securities activities. On this view, territorial limitations on regulators' reach are a problem to be overcome, since territorial competition for issuers and investors may result in a race to the bottom for regulatory standards. The SEC's harmonization efforts respond to this perceived problem by pushing regulatory standards upward across the board.

For issuer choice advocates, of course, this is exactly the wrong way to proceed. For them, the appropriate relationship among national regulatory regimes is as competitors, and the appropriate international system is one that forces national regimes to compete with each other to

58. IOSCO membership includes the national regulatory authorities of most nations. See Int'l Org. of Sec. Comm'ns, IOSCO Membership Lists, at http://www.iosco.org/memberslist.html (last modified Jan. 7, 2003).

59. Foreign issuers in the Unites States now file their annual reports on form 20F, adopted by the SEC in 1999, which conforms to IOSCO international disclosure standards. See International Disclosure Standards, Exchange Act Release No. 33-7745, 70 SEC Docket $(\mathrm{CCH})$, at 1474 (Sept. 28, 1999) (adopting release); see also INTERNATIONAL Developments: The SEC's International Program 752 (PLI Order No. B0-017O February 2002) [hereinafter SEC's InTERnAtional Program] (describing SEC involvement with IASB, IOSCO); Enrico Colombatto \& Jonathan R. Macey, A Public Choice Model of International Economic Cooperation and the Decline of the Nation State, 18 CARDOZO L. REv. 925, 953 (1996) (discussing harmonization of insider trading rules); David Zaring, International Law by Other Means: The Twilight Existence of International Financial Regulatory Organizations, 33 TEX. INT'L L.J. 281, 302 (1998) (suggesting that "the SEC plays an overwhelmingly influential role in IOSCO" (citing TONY PORTER, StATES, MARKETS AND REgIMES IN GLOBAL FinANCE 122-23 (1993))).

60. See SEC's INTERNATIONAL PROGRAM, supra note 59, at 772-73; STEINBERG, supra note 42, at 214 (discussing SEC Memoranda of Understanding (MOUs) with other nations). These MOUs typically include not only understandings on the rendering of information assistance but also obligations concerning confidentiality and permissible uses of information so obtained. Id. Technical assistance by the SEC may also be contemplated. See id. at 231. 
offer regulation that issuers and investors want. ${ }^{61}$ Harmonization would simply create an international "regulatory cartel," ${ }^{, 62}$ susceptible to the same inefficiencies that plague territorial regulatory monopolies.

In any event, competition and harmonization offer two opposing alternatives to the unadorned application of national regulation to international transactions.

\section{B. Issuer Choice}

The conflicts problems described above argue for some global approach to securities regulation. According to its proponents, issuer choice offers a regulatory structure that is both global in scope and efficient. ${ }^{63}$ Under the current territorially-based approach to securities regulation, each national regulatory agency enjoys something of a "monopoly" in terms of the regulation it chooses to supply within its jurisdiction. Issuers and investors wishing to transact are unavoidably bound by the national securities laws of the jurisdiction in which they are deemed to have transacted. This territorially determined choice of securities regulatory regime may not be optimal for the parties to any given transaction. Regulatory monopolists have insufficient incentive and insufficient information to be able to offer optimal regulation. ${ }^{64}$ The issuer choice solution is to untether national capital markets from their respective national regulatory regimes, thereby breaking the regulatory monopolies. Allowing issuers to choose their securities regulation forces regulators to compete to supply regulation that transacting parties want.

The idea of issuer choice is in essence a spin-off from the U.S. corporate charter competition model made popular by Romano and others. The basic rationale for issuer choice parallels the rationale behind U.S. corporate charter competition. Think of law as a product. Competition among suppliers results in products that better satisfy consumer preferences. As with state competition for corporate charters in the United States, the argument goes, competition among nations' securities regulators to meet consumer demand may produce more efficient regulation. ${ }^{65}$

61. Moreover, commentators have suggested that attempts at regulatory harmonization are driven by national regulators' desire to preserve their own authority from dissipation, as targets of regulation exit to less heavily regulated jurisdictions. See Colombatto \& Macey, supra note 59, at 955.

62. Romano, Need for Competition, supra note 10, at 390.

63. See id. at 392-97; Choi \& Guzman, supra note 11, at 916-17.

64. See Romano, Need for Competition, supra note 10, at 390-96.

65. See infra notes 108-09 and accompanying text. 
The issuer choice approach solves the conflicts problem as well, according to proponents. It leaves the global choice of law to each firm to decide. Because the firm's choice applies worldwide, conflicts do not arise. The issuer choice promise, then, is not only for efficient regulation but for efficient regulation on a global scale. ${ }^{66}$

\section{ROMANO’S PROPOSAL}

Romano's initial issuer choice proposal focused primarily on U.S. issuers in the U.S. securities market. ${ }^{67}$ She advocated that federal regulation be optional, that U.S. states be allowed to offer competing securities regulatory regimes, and that firms be allowed to choose from among them. Firms could declare their choice of regime in their corporate charters. ${ }^{68}$ Her proposal additionally included two investor protections. First, the firm's chosen regulatory regime would have to be explicitly disclosed to investors. ${ }^{69}$ Second, the firm's selected regime could be changed only with shareholder approval. ${ }^{70}$

Romano has proposed to extend this approach internationally, arguing generally that issuers should be allowed unrestrained choice in terms of a regulatory regime. ${ }^{71}$ Romano does enumerate basic disclosure requirements concerning the effects of international regime choice and the nature of an issuer's selected regime. ${ }^{72}$ She suggests that disclosure specifically include notice that an investor's domestic civil and criminal liability rules would not necessarily apply to the investor's transactions. ${ }^{73}$ In addition, if a firm's selected regime did not include fraud liability or financial disclosure requirements, or if the regime lacked the capacity to prosecute violations of such rules, those deficiencies should also be disclosed to prospective investors. ${ }^{74}$ Romano also echoes her requirement

66. See Choi \& Guzman, supra note 11, at 914-16; Romano, Need for Competition, supra note 10, at 389.

67. See Romano, Empowering Investors, supra note 10, at 2361.

68. Romano also considered the possibility that firms' chosen securities law would follow from their choice of state of incorporation. However, she concluded that an independent choice of securities law most closely comports with a market approach. See id. at 2410 .

69. Brokers would be required to inform prospective securities purchasers at the time of purchase; issuers would be required to disclose in writing at the time of any public offering; and the applicable regulation would have to be indicated on the security itself. See id. at 2413.

70. See id. at 2415.

71. Romano, Need for Competition, supra note 10, at 390.

72. Id. at 401 .

73. Id. at 401-02.

74. Id. 
of shareholder approval for regime changes. ${ }^{75}$ Finally, Romano anticipates that issuers, desiring to give international investors some assurance as to issuers' amenability to suit, would consent to suit in appropriate fora in their offering and listing documents. ${ }^{76}$ Each nation's judiciary should therefore be instructed to respect these forum selection clauses. ${ }^{77}$

\section{2. "PORTABLE RECIPROCITY” OF CHOI \& GUZMAN}

Choi and Guzman conceptualize their proposal- "portable reciprocity" - as a simple extension of existing bilateral recognition agreements. Under the typical recognition or "passport" agreement, two countries agree that a party from one country need only comply with its home country regulation in order to be able to transact in the other "host" country. Each party's home country regulation in effect "travels" with it for purposes of transacting in the host country. ${ }^{78}$ For example, the United States and Canada have agreed to a Multijurisdictional Disclosure System (MJDS), which basically permits a firm from either country to rely on its home country disclosure documents when issuing securities in the other country. ${ }^{79}$

Portable reciprocity extends this basic approach. Choi and Guzman envision a regime of multilateral reciprocity, but instead of issuers being able merely to travel with their home country rules, every issuer would be permitted to choose the securities regulatory regime of any participating country. The choice of regime would be recognized for the issuer's securities offered or traded in each participating country, regardless of the nationality or domicile of the issuer or investor or the location of any particular transaction. ${ }^{80}$ Like Romano, Choi and Guzman emphasize the

75. Id at 401.

76. Id.

77. Id.

78. See Frederick Tung, Passports, Private Choice, and Private Interests: Regulatory Competition and Cooperation in Corporate, Securities, and Bankruptcy Law, 3 CHI. J. INT'L L. 369 (2002) (discussing passport arrangements). Choi \& Guzman refer to these arrangements as "normal” reciprocity. Choi \& Guzman, supra note 11, at 918 \& n.60.

79. See Multijurisdictional Disclosure and Modifications to the Current Registration and Reporting System for Canadian Issuers, Securities Act Release No. 6902, Exchange Act Release No. 29,354, Trust Indenture Act Release No. 2267, 56 Fed. Reg. 30,036 (July 1, 1991); Notice of National Policy Statement No. 45, 14 OSC Bull. 2844 (1991); see also Choi \& Guzman, supra note 11, at 918 (describing MJDS); Tung, supra note 78, at 378-79 (same).

80. See Choi \& Guzman, supra note 11, at 922. 
importance of disclosing to investors the firm's chosen regulatory regime. ${ }^{81}$

\section{ASSUMED INCENTIVES OF REGULATORS}

Central to issuer choice proposals are the assumed incentives and motivations of national regulators. According to these proposals, bureaucracies thrive by expanding their reach, and in the case of securities regulation, the number and size of firms being regulated, and the volume of securities offerings and trading, are regulators' maximands. ${ }^{82}$ Under regulatory monopoly, regulators are too easily tempted to pursue their own bureaucratic aggrandizement without regard for the public interest. ${ }^{83}$ Romano cites as one example the SEC's repeated attempts to expand its jurisdiction to include equity derivatives. ${ }^{84} \mathrm{By}$ contrast, issuer choice would force national regulatory regimes to compete with one another to offer efficient regulatory "products"-those that would be popular with issuers and investors. Competition, the argument goes, would effectively harness regulators' temptations toward bureaucratic aggrandizement in the service of more efficient regulation. Regulators would be responsive to the desires of issuers and investors because that would be their only available avenue for augmenting their regulatory purview. Regulators would aggressively push their products in order to expand their regulatory authority and augment the importance of their agencies. They might also charge fees for the use of their regulatory apparatus, thereby benefiting the national fisc.

Besides the pursuit of direct bureaucratic benefits under issuer choice, regulators might also wish to benefit important constituents in order to obtain political support. Offering popular regulation would serve that end as well. Because issuers choosing a country's regime would also likely offer their securities in that jurisdiction, successful sales of regulation would result in an increase in the volume of securities sold and traded nationally. ${ }^{85}$ The increase in securities activity redounds to the

81. See id. at 926 .

82. "[R]egulators prefer to have within their jurisdiction more rather than fewer regulated firms and transactions ...” Romano, Need for Competition, supra note 10, at 393 (citing William A. NisKanen, JR., BurEAUCRACY AND REPRESENTATIVE GOVERNMENT 38-41 (1971)).

83. Niskanen argues that the rational bureaucrat will seek to maximize her bureau's budget, even a bureaucrat motivated to pursue the public interest. See NISKANEN, supra note 82, at 38.

84. See Romano, Need for Competition, supra note 10, at 399.

85. See Choi \& Guzman, supra note 11, at 923. Issuers recognize that local investors are likely to be most familiar with local regulation and most comfortable with 
benefit of both regulators and their important constituent, the national securities industry. In addition, it would also increase the range of readily available investment options for each nation's investors. ${ }^{86}$ Moreover, the successful establishment or expansion of a local financial center creates jobs and generates tax revenues, further enhancing the prestige of the regulators who oversee the industry. ${ }^{87}$ The current system, which ties access to domestic capital markets to compliance with domestic regulation, impedes capital flows. Issuer choice would allow issuers to sell securities in each national jurisdiction without having to pay what is effectively an "entry fee" in the form of national regulatory compliance.

\section{OTHER REFINEMENTS}

Besides appropriate incentives, an issuer choice regime would also provide regulators with good information with which to design desirable regulation. Individual decisions of issuers in choosing their regulatory regimes would provide "market" information to regulators, who could respond to their consumers by altering their regulatory products to maximize adoptions. "[T]here will be a net flow of capital to firms operating under the regimes investors prefer and, hence, a feedback mechanism for regulators to ascertain which rules are cost effective.” ${ }^{88}$ By contrast, under the current territorial system, national regulators not subject to competitive pressures do not have good information with which to craft optimal rules. ${ }^{89}$

Issuer choice proponents are also confident that firm managers could not use their regulatory choices to investors' disadvantage. Efficient capital markets can "price" the regulatory regimes selected, thereby precluding managers from pursuing their own interests at the expense of investors. ${ }^{90}$ For managers choosing regimes that provide insufficient

local enforcement mechanisms. Therefore, choosing local law is likely to enhance the popularity of any particular offering among local investors. See id.

86. See id. at 922.

87. See Stephen J. Choi \& Andrew T. Guzman, National Laws, International Money: Regulation in a Global Capital Market, 65 FordHAM L. REV. 1855, 1861 (1997).

88. Romano, Need for Competition, supra note 10, at 390.

89. See id. For international bureaucracies attempting to negotiate uniform rules, but not subject even to democratic accountability, the incentive and information problems are even worse. See Paul B. Stephan, Regulatory Cooperation and Competition: The Search for Virtue, in U. VA. Sch. LAW, LEGAL StUdies WORKING PAPERS SERIES 99-12 (June 1999).

90. Romano notes:

In today's global financial markets, which are dominated by sophisticated institutional investors, competition among securities regulators would not only protect investors, both large and small, but also would provide a superior regulatory regime.... In competitive capital markets, issuers of securities 
investor protections-for example, a regime may allow managerial opportunism - their firms would suffer in the capital markets. Investors would pay less for the securities of those issuers than if a more investorprotective regime had been selected. ${ }^{91}$ Because a firm's managers desire to minimize the firm's costs of capital and maximize offering proceeds and post-offer trading values, they would, given the choice, select the regulatory regime that is optimal for the firm's investors.

Where Romano and Choi and Guzman tend to differ is in the direction they believe the competition will lead. Romano believes that securities regulation will race to the top. For Romano, the starting point for issuer choice in securities regulation is the declared triumph of U.S. corporate charter competition. Free choice of firms' states of incorporation and facilitative conflicts rules create a national market for corporate law, in which states are producers competing for consumers of corporate law. According to Romano, this competition produces corporate law that maximizes firm values and investors' returns. ${ }^{92}$ Additionally, the same dynamics that have driven this race to the top can be harnessed to produce optimal securities regulation. In her view, competition over securities regulation will similarly cause regulatory regimes to converge around the rules that issuers and investors want. ${ }^{93}$

Choi and Guzman are less convinced about convergence and agnostic as to its direction. Instead, they posit the heterogeneity of issuers and investors. Not all issuers are alike, so a regulatory regime that is suitable for one may not be desirable to another. In their view, the beauty

have incentives to select regulatory regimes that protect investors from exploitation by insiders, because such choices lower the cost of capital. Even though individual investors may be poorly informed regarding what level of disclosure or other protective mechanisms are necessary, because the distribution of equity returns is pro-rated by share ownership and there is one price for shares, informed institutional investors dictate the regulatory choices of issuers and less-informed investors are thereby also protected.

Romano, Need for Competition, supra note 10, at 389; see also Romano, Empowering Investors, supra note 10, at 2366-67. Choi has acknowledged that not all firms' securities trade in efficient markets. Responding to issuer choice critics, Choi proposes the partitioning of markets in order to allow issuer choice to apply to that part of the market in which it is most likely to function best. He would limit issuer choice to (i) "efficient market" companies - those for which securities markets can accurately price regulatory choices-and (ii) non-efficient market companies that agree to allow only sophisticated investors to hold their securities. See Choi, supra note 17, at 818-19.

91. See Romano, Empowering Investors, supra note 10, at 2366-67; Romano, Need for Competition, supra note 10, at 493.

92. Romano, Need for Competition, supra note 10, at 494.

93. See Romano, Empowering Investors, supra note 10, at 2387. More recently, Romano has considered the possibility that regulatory diversity would result, which would stand to benefit heterogeneous issuers. See Romano, Need for Competition, supra note 10, at 395-96. 
of competition is that it generates regulatory diversity, allowing firms to choose from an array of regulatory options, and allowing investors a choice as to the regulatory regimes under which they will invest. ${ }^{94}$ In this way, heterogeneous issuers and investors are more likely to be matched, thereby eliminating the deadweight losses associated with territorially imposed regulation.

\section{Who Will Supply Choice of Law Rules?}

To date, the debate over issuer choice has focused primarily on the demand side - the behavior of firm managers and investors-and whether issuer choice will work as predicted. Merritt Fox and Roberta Romano have debated whether the existence of interfirm externalities from corporate disclosure preclude firm managers from making socially optimal regime choices. ${ }^{95} \mathrm{Jim}$ Cox has expressed doubt that securities markets can efficiently price differences among regulatory regimes. ${ }^{96}$ Echoing the debate over U.S. corporate charter competition, ${ }^{97}$ Romano predicts a race to the top from issuer choice of securities regulation, while Fox and Cox each predict a race to the bottom - that is, competition will produce socially undesirable laws. And Choi and Guzman predict a separating equilibrium, asserting that heterogeneity of issuers will result in different jurisdictions offering different regulatory regimes to meet issuers' varying needs.

94. See Choi \& Guzman, supra note 11 , at 917.

95. According to Fox, even absent agency problems, interfirm externalities cause a divergence between a firm's private marginal cost of disclosure and social marginal cost. Because private cost will be higher than social cost at all levels of disclosure, managers given a choice of disclosure regime will always choose a socially suboptimal level of disclosure. Romano disputes these assertions, arguing among other things that the presence of institutional investors internalizes any interfirm externalities. Compare Fox, Political Economy, supra note 19, at 749, and Fox, Retaining Mandatory Securities Disclosure, supra note 19, at 1345, and Fox, The Issuer Choice Debate, supra note 19, with Romano, Need for Competition, supra note 10. Fox also argues that including public choice considerations in the analysis shows that an international race to the bottom may result. See Fox, Political Economy, supra note 19, at 793. He proposes his own novel allocation of regulatory jurisdiction, arguing that it should be based on issuer nationality. A country should regulate only its domestic issuers, those whose "economic center of gravity” is located there. See Merritt B. Fox, Securities Disclosure in a Globalizing Market: Who Should Regulate Whom, 95 MicH. L. REV. 2498, 2506 (1997).

96. See Cox, supra note 20, at 1234.

97. See, e.g., Roberta Romano, The Genius of American Corporate Law (1993) (arguing that competition for corporate charters among U.S. states has resulted in more efficient corporate law overall); William L. Cary, Federalism and Corporate Law: Reflections upon Delaware, 83 YALE L.J. 663, 666 (1974) (asserting that result of corporate charter competition has been a "race for the bottom"). 
The supply side of issuer choice, however-the story of how regulators and other government suppliers of law behave-has not been much questioned.$^{98}$ For issuer choice proponents, both the diagnosis of the disease of regulatory "monopoly" and its antidote rely on standard public choice assumptions - that regulators regulate in order to garner rents for themselves and favored constituencies. ${ }^{99}$ Under regulatory monopoly, the analysis goes, regulators have insufficient incentive to be responsive to the needs of issuers and investors. Once forced to compete, however, regulators' survival and their ability to benefit important constituents will depend on designing efficient products-i.e., rules that issuers and investors want.

A basic question exists, however, concerning the international framework for competition. Incentives to supply socially optimal regulation would operate according to issuer choice predictions only if regulators truly competed in a well-functioning market for securities law. But they don't. Analysts on all sides have focused on substantive rules and the dynamics of competition over those rules. ${ }^{100}$ But they have ignored the fact that competition over substantive rules requires international cooperation in structuring the market in which states would compete. ${ }^{101}$ In fact, the political actors that would in theory compete over substantive securities law under issuer choice-regulators and other law givers-are also the ones whose cooperation and support would be required to create the market at the outset.

Regulators or other law givers would have to agree to a choice of law rule honoring firms' private choice. Each state would have to give up its traditional territorial jurisdiction for its securities law, and agree instead to apply whatever law a firm might choose. Issuer choice proponents have failed to explain how the global market for law will come to pass or who

98. As such, issuer choice is of a piece with the competitive federalism literature that relies on "efficiency-driven, demand-side arguments that assume away politics and institutions . . . . Missing from the . . literature is a treatment of the institutional supply side.” Jonathan Rodden \& Susan Rose-Ackerman, Does Federalism Preserve Markets?, 83 VA. L. REV. 1521, 1532 (1997).

99. See supra notes 82-86 and accompanying text.

100. See supra notes 95-97 and accompanying text.

101. "[T]he formal prerequisite of a cooperative approach to regulatory competition is the existence of a consensus about either the enforceability of explicit choices of law or the content of choice-of-law rules that turn on transactional forms that parties can manipulate.” Stephan, supra note 89, at 12. Moreover, stable equilibria cannot occur without some sort of centralized institutional framework to facilitate competition. See Joel P. Trachtman, Regulatory Competition and Regulatory Jurisdiction in International Securities Regulation, in REgUlATORY COMPETITION AND ECONOMIC INTEGRATION 289, 294 (Daniel C. Esty \& Damien Geradin eds., 2001). 
will have sufficient incentive to supply the right choice of law rules. The market just exists. ${ }^{102}$

Because the requisite choice of law rules for international issuer choice do not exist, nations would have to supply it. ${ }^{103}$ Analysts of regulatory competition do not typically think of this as a problem of supply. Working from the model of U.S. federalism, the framework for competition is already in place. Therefore, the rules needed to create it are not regarded as part of the product states offer. But with the move from U.S. federalism to international competition, the nature of the product must change in this fundamental way to include facilitative choice of law rules.

What incentives would regulators have to supply this critical element? Ironically, the very incentives that would theoretically drive regulators to vigorous competition on substantive regulation-assuming an international framework for competition already existed-would likely also drive them to resist competition in the first place. If all the world's securities regulators could agree to respect firms' private choice, then the pursuit of bureaucratic aggrandizement might cause each regulator to respond to consumer preferences in order to maximize the number of firms under her regulatory authority. But even if that were true, it would not explain why regulators would willingly surrender their regulatory monopolies in the first place. Why would a monopolist-regulatory or otherwise-prefer competition to a cozy monopoly? For the regulatory monopolist intent on the pursuit of bureaucratic aggrandizement, giving up the monopoly in favor of competition would seem an odd way to

102. Choi and Guzman merely posit international agreements implementing the appropriate choice-of-law rules. Likewise, Romano simply assumes national actorsexecutives and legislatures - in each jurisdiction would sign the right treaties to require states to respect private choice of foreign securities law. "Mutual recognition of statutory securities domicile would . . . have to be effectuated by a treaty or other executive agreement . . . . This undoubtedly complicates the implementation of a competitive international regime.” Romano, Need for Competition, supra note 10, at 398. Romano recognizes the theoretical possibility that the SEC could exercise its exemptive powers to create competition. See id. Alan Palmiter has made the same suggestion. See Alan R. Palmiter, Toward Disclosure Choice in Securities Offerings, 1999 Colum. Bus. L. Rev. 1. However, given Romano's assumptions about SEC incentives, she justifiably doubts that it would do so. She ultimately recognizes that some form of legislative or executive action would be necessary to create a competitive regime. See Romano, Need for Competition, supra note 10, at 398. Despite this bifurcation of regulatory versus national officials, it remains a supply problem, albeit involving different officials that also have significant influence over the texture of securities law. And no theory has addressed this problem.

103. "Within the U.S. federal system, stability is provided by the ability of the federal government to intercede; this is an important distinction between regulatory competition in the U.S. domestic context and regulatory competition in the international context. In the international context, we must build and empower a central authority." Trachtman, supra note 101, at 295. 
proceed. Surely a move from monopoly to competition can only threaten the assumed goals of the maximizing bureaucrat. As I explain below, the maximizing bureaucrat's more likely strategy is to pursue regulatory price discrimination like a good monopolist.

Once we acknowledge that the emergence of appropriate choice of law rules cannot simply be treated as exogenous, but must be endogenous to our model, then providing a consistent description of regulators' incentives that results in the emergence of both an international framework for competition and competition over substantive rules becomes quite tricky. Whether such a story can be told is doubtful.

To be sure, regulators - as distinct from legislators and executive officials-may not necessarily enjoy a veto power over these choice of law rules and whether a competitive system is realized. In all likelihood, legislative and executive action would be required to achieve the necessary international cooperation in any event. ${ }^{104}$ However, regulators not only design substantive rules; they may also have significant influence over the jurisdictional scope of their substantive law products. ${ }^{105}$ Regulators' opposition to issuer choice would surely make implementation more difficult politically. ${ }^{106}$ Moreover, recognizing the necessity of legislative and executive action simply moves the question to a higher level. Under what circumstances would national officials be willing to supply the right choice of law rules for regulatory competition?

In Parts II and III of this Article, I discuss these questions about the incentives and constraints of regulators and other lawmakers with respect to issuer choice. Before proceeding to those analyses, I briefly discuss corporate charter competition in the United States and the choice of law rule that emerged among U.S. states to facilitate it. I suggest important conditions that led to its emergence, and I distinguish those conditions from the current international setting for securities regulation. As earlier noted, the model of U.S. corporate charter competition figures prominently in the affirmative case made for issuer choice. However, the U.S. and international settings are different in important respects. That facilitative choice of law rules could emerge among U.S. states thus portends little for the prospects of similar developments for international issuer choice.

104. See Romano, Need for Competition, supra note 10, at 399-400.

105. See Choi \& Guzman, supra note 13, at 209 (discussing SEC approaches to extraterritorial jurisdiction concerning securities offerings and antifraud rules).

106. See infra Part III.A. 


\section{Corporate Charter Competition in the United States}

Under U.S. corporate charter competition, the internal affairs rule enables the competition that exists. While each state offers its own corporation law, states generally accept and apply the so-called internal affairs rule for their choice of law regarding a corporation's internal affairs - the relations among a firm's shareholders and managers. ${ }^{107}$ Under this rule, the firm's chosen corporation law will govern its internal affairs, regardless of the location of the firm's headquarters, assets, or personnel, regardless of where particular transactions occur or particular persons reside. ${ }^{108}$ Therefore, a firm may incorporate under the corporation law of any state, and its choice will be respected in other states. This common respect for firm choice effectively creates a common market for corporate law. States act as producers competing nationwide for consumers of corporate law. Because states may garner significant fees with successful sales of corporate charters, as well as benefit local constituents, they have some incentive to offer corporate law that firm managers and investors prefer. According to regulatory competition advocates, this competition among states produces corporate law that maximizes firm values and investors' returns. ${ }^{109}$

Moving to the international context, however, no mechanism like the internal affairs rule exists. That consensus could emerge among U.S. states regarding the internal affairs rule does not imply that a similar choice of law rule and competitive framework could spontaneously develop internationally for securities regulation. The background conditions are dissimilar.

U.S. states are of course part of a federal system governed under the Constitution, and no similar institutional framework exists for independent nations. Scholars disagree as to the relative importance of Constitutional influences on the evolution of the internal affairs rule. ${ }^{110}$

107. See Restatement (Second) of Conflicts § 302(2) (1971); Model Bus. CORP. ACT § 15.05(c) (1984).

108. A handful of states-California and New York most notably-impose their own local requirements on certain foreign corporations as to certain issues. See CAL. CORP. CODE § 2115 (West 1990 \& Supp. 2002); N.Y. Bus. CORP. LAW §§ 1317-1320 (West 1986 \& Supp. 2002).

109. See Romano, supra note 97, at 14-51. Recent scholarship has questioned whether states actually do compete for charters. See Lucian Arye Bebchuk \& Assaf Hamdani, Vigorous Race or Leisurely Walk: Reconsidering the Debate on State Competition over Corporate Charters, 112 YALE L.J. 553 (2002); Marcel Kahan \& Ehud Kamar, The Myth of State Competition in Corporate Law, 55 STAN. L. Rev. 679 (2002).

110. See Bruce H. Kobayashi \& Larry E. Ribstein, Contract and Jurisdictional Freedom, in The FALl AND Rise of FreEdom of Contract 325, 333 (F.H. Buckley ed., 1999). 
However, even on the most decentralized, bottom-up view of things-that each state unilaterally and independently arrived at the internal affairs rule-Constitutional guaranties of unimpeded interstate commerce played a critical role. According to this view, in the absence of state-by-state trade barriers, firms could generally avoid unattractive corporate law by simply relocating out of an unattractive jurisdiction, while continuing to sell products into the unfriendly jurisdiction. ${ }^{111}$ This relatively easy exit option meant that a state had little to gain and something to lose-in terms of local tax base, business opportunities, employment, and other positive spillovers-by attempting to impose local corporate law in the face of a firm's election of another state's law. Therefore, local interests in each state would have favored local recognition of out-of-state incorporation, supporting the internal affairs rule and precluding the formation of interest groups favoring territoriality in corporate law. ${ }^{112}$ On this view, put simply, the threat of firms' physical exit to avoid a state's undesirable corporate law forced each state to offer virtual exitavoidance of the unattractive local law without the need for physical exit-through adoption of the internal affairs rule. ${ }^{113}$

Historically, however, different conditions have obtained for firm mobility and securities law recognition in the international context. It should not surprise, therefore, that interest group alignments for securities law recognition among nations would have developed quite differently from the case of corporation law among U.S. states. Firms historically have not enjoyed nearly the physical mobility internationally that they enjoy within the United States. Their headquarters and key operations, employees, relationships, goodwill, and assets are not readily transplanted internationally without significant loss of value. Moreover, firms would typically have had difficulty avoiding application of their home country securities laws. Because the costs of capital are likely to be lowest at

111. Territorial application of local corporate law typically involves rules to protect local investors, and exercise of prescriptive jurisdiction is typically based on the predominance of firm assets, employees, sales, income, or investors in the prescribing jurisdiction. See supra note 108 and sources cited therein.

112. See William J. Carney, The Political Economy of Competition for Corporate Charters, 26 J. LEgal STUD. 303, 312 (1997); Kobayashi \& Ribstein, supra note 110. Comparing the U.S. federal system with company law within the European Community (EC), Carney has detailed the link between the lack of competition among EC countries and interest group influences resulting in harmonization of interest group protections through EC company law directives. See Carney, supra, at 318.

113. States' other obvious alternative-reforming the unattractive aspects of their corporate laws - has apparently also been pursued. Scholars have noted the substantial uniformity across states' corporate law statutes. See Bernard S. Black, Is Corporate Law Trivial?: A Political and Economic Analysis, 84 Nw. U. L. REV. 542, 588 (1990); Roberta Romano, Law as a Product: Some Pieces of the Incorporation Puzzle, 1 J.L. Econ. \& ORG. 225, 235 (1985). 
home ${ }^{114}$ firms issuing securities generally cannot avoid issuing in their home jurisdictions. ${ }^{115}$ It is this "hometown" effect that guaranties the regulatory monopolies that issuer choice proponents condemn. Bound to their home country securities markets, firms are likewise bound to home country securities law. Home country interests with economic stakes in preserving and promoting home country securities activity-for example, stock exchanges and investment banks-would not have felt threatened by the possibility of firm exit. Lawmakers would therefore not have felt any local pressure to offer virtual exit-in the form of issuer choice- to forestall firms' physical exit. There would have been no push to forsake territorial securities law in deference to firms' alternative choices.

Instead, as I argue below, just the opposite has occurred. Within each independent nation, the operation of a national securities regulatory regime, combined with the historical difficulties of firms' physical exit from their home jurisdictions, would not surprisingly produce important interest groups with stakes in territorial regulation. ${ }^{116}$ These interest groups-as well as regulators-will wish to preserve regulatory monopoly, making issuer choice unlikely. ${ }^{117}$

\section{REgulators’ CALCUluS}

Assuming that regulators were not public regarding but only rationally self-interested, it is far from clear that regulators in any country would willingly give up their territorial monopolies to open competition.

114. A firm's capital costs are likely to be lowest in its home country because home country investors are likely to enjoy informational advantages over foreign investors with respect to assessing the firm's value and prospects. See Fox, Political Economy, supra note 19, at 770-71 ("Despite the burden of compliance, avoiding the U.S. market traditionally has not made sense for U.S. issuers since the United States is the residence of a large portion of their most likely potential investors.”); Romano, supra note 10, at 2397 ("[R]esort solely to foreign capital markets for financing is not a viable option for publicly traded U.S. firms.”). Under the EU's “passport” system for securities listings and public offerings, a firm could choose a regulatory regime other than that of its home state by making its initial offering in another member state. But "[i]n reality, very few issuers apparently choose to list outside of their home country given that issuers often find the warmest reception for their securities in their home markets.” Jackson \& Pan, supra note 32, at $678-79 \&$ n.70.

115. For a discussion of the exceptional case of Israeli high-tech firms avoiding the Israeli securities market, see infra Part II.D. This exceptional situation would most typically involve firms from a country with a small and unattractive securities market, what I term a “regulatory price-taking” jurisdiction. See infra Part III.B.

116. Not only do interest groups affect policies, but policies may also produce interest groups. See Paul Pierson, When Effect Becomes Cause: Policy Feedback and Political Change, 45 WorLd Politics 595 (1993) (noting that "policies produce politics").

117. See infra Part III.B. 
A regulator would accept issuer choice and abandon territorial choice of law rules only if she could be confident ex ante that her prospective private benefits under issuer choice-in terms of bureaucratic aggrandizement and the ability to favor important domestic interest groups - would exceed those under her existing monopoly. ${ }^{118}$

A regulator enjoying a healthy monopoly would be unlikely to prefer the vagaries of competition under issuer choice. She would have to be extremely confident in the ability of her domestic regime to compete internationally in terms of selling her regulatory product. ${ }^{119}$ In addition, she would have to be amenable to the loss of political slack that would result from regulatory competition. ${ }^{120}$ Assuming a risk averse regulator further narrows the possibilities for choice of law arrangements leading to competition.

On the other hand, against their druthers, some regulators might be forced to compete. As with any monopoly, a regulator's market power may be dissipated by technological or other innovations. With securities transactions, the increased mobility of issuers and investors may enable their figurative exit from particular jurisdictions with unattractive regulatory or other characteristics. Traditionally, issuers and investors transacted primarily or exclusively in their home jurisdictions, where they were most familiar with the overall business and investment climatelaw, custom, language, culture, currency, and the like. Israeli firms issued their securities in Israel; Japanese investors bought securities of Japanese issuers in Japan. ${ }^{121}$ However, especially for countries with small, illiquid

118. As for social benefits, playing issuer choice might be a positive-sum game globally. As issuer choice proponents argue, marginal issuers that might not be willing or able to issue securities under a territorially-based system might be able to find a desirable regulatory regime under issuer choice, such that increased issuing and trading volumes would result. And investors would benefit from expanded investment opportunities. However, according to our public choice assumptions, territorially-based regulators care only about their private benefits, so a regulator would be unmoved by appeals to social benefits. She would support issuer choice only if she could be confident it would augment her private benefits.

119. Regulators may in addition embrace inertia for behavioral reasons. Loss aversion from regret avoidance may cause individuals unduly to favor the status quo. See Russell Korobkin, Inertia and Preference in Contract Negotiation: The Psychological Power of Default Rules and Form Terms, 51 VAND. L. REV. 1583 (1998). Regulators are not immune from this status quo bias. See Stephen M. Bainbridge, Mandatory Disclosure: A Behavioral Analysis, 68 U. CiN. L. REV. 1023, 1056 (2000) (pointing out that regulators must be "endogenized" in any analysis seeking to rely on law to correct bias-induced market failures). But organizations may to some extent perform a "debiasing" role. See Chip Heath et al., Cognitive Repairs: How Organizational Practices Can Compensate for Individual Shortcomings, 20 RES. IN ORG'L BEHAV. 1 (1998).

120. $C f$. Levine \& Forrence, infra note 187 (discussing political slack that allows regulators to favor private interests).

121. See supra note 114 . 
securities markets, the increasing mobility of local issuers and investors may enable them to find acceptable substitutes outside their home jurisdictions. A regulator in such a jurisdiction may be forced to compete to some extent as her market power wanes.

In this Part, I examine the incentives of regulators to bring about the envisioned international issuer choice regime. In particular, I discuss regulators' incentives with respect to choice of law rules, the structuring of which could either facilitate or impede regulatory competition. Adopting the assumptions of issuer choice proponents regarding regulators' incentives, ${ }^{122} \mathrm{I}$ not only show that regulators would oppose adoption of rules recognizing private choice-a prospect that issuer choice advocates have already noted ${ }^{123}$ _but I also describe their optimal strategies in pursuing their assumed maximands. Treating regulation as a "price" that regulators charge for access to their national capital markets, I discuss the differing strategies of regulators from "price-setting" and "price-taking" jurisdictions. In particular, regulators in price-setting jurisdictions will adopt a strategy of regulatory price discrimination, a strategy inconsistent with issuer choice.

\section{A. Regulatory Monopoly and Regulation as Price}

Because territorially-based securities regulation ties capital markets to national regulatory regimes, we can think of regulation as a "price" that a national regulator charges issuers in order to have their securities issued and traded in the national market. ${ }^{124}$ For each issuer, we may assume that an optimal set of securities regulations exists that maximizes firm value. ${ }^{125}$ Call that the issuer's "regulatory ideal." ${ }^{\text {"126 }}$ To the extent that a nation's actual regulatory regime diverges from an issuer's regulatory ideal, the regulation is by definition value-decreasing. It effectively

122. The supposition that lawmakers would be sufficiently motivated to compete has not gone uncontested. See Douglas J. Cumming \& Jeffrey G. MacIntosh, The Role of Interjurisdictional Competition in Shaping Canadian Corporate Law, 20 INT'L REV. L. \& ECON. 141 (2000); Susan Rose-Ackerman, Risk Taking and Reelection: Does Federalism Promote Innovation?, 9 J. LEGAL STUD. 593, 594, 605-06 (1980); see also supra note 109 and sources cited therein.

123. See Romano, Need for Competition, supra note 10, at 399.

124. Cf. Robert Cooter, Prices and Sanctions, 84 ColuM. L. Rev. 1523, 1525 (1984) (defining a price as a payment of money that is required in order to do what is permitted).

125. This definition assumes away the possibility of agency costs that could preclude an issuer from desiring value-maximizing law. $C f$. Choi \& Guzman, supra note 87, at 1864 (defining regulatory ideal within a country as the regulation issuers and investors within the country would choose if they could costlessly contract).

126. Whether the regulatory ideals for various issuers converge or diverge does not matter for our purposes. 
exacts a price from the issuer for the privilege of engaging in securities activities within the jurisdiction.

As so described, a "high" price would not necessarily reflect overregulation, but a large difference between the regulatory ideal and the actual regulation. A regime that is too lax might therefore exact a high regulatory price, as well as a regime that is too stringent. Remaining true to our assumptions about regulators' incentives, however, issuer choice advocates generally assume that the degree of actual regulation-at least in important jurisdictions-exceeds the regulatory ideal. ${ }^{127}$ Pursuit of bureaucratic aggrandizement causes regulators to err on the side of overregulation, not under regulation. For present purposes, we may adopt this perspective and assume that regulators will attempt to charge as high a price as possible on the side of overregulation. ${ }^{128}$

Treating national regulation as the price of entry into a national securities market, we may further observe that national markets are not all equally attractive. Some are more attractive than others, and this will affect their regulatory pricing strategies. Although each national regulator probably enjoys some degree of market power, primarily with respect to local issuers and investors, improved investor and issuer mobility may diminish regulators' market power even as to these traditionally captured consumers. Especially for issuers and investors from countries with small, illiquid national markets, modern telecommunications and other technological innovations may offer access to more intrinsically attractive capital markets. As acceptable substitutes for the local securities market become available, the national regulator's market power diminishes and her regulatory monopoly becomes contested. Suboptimal regulation may drive issuers and investors to figuratively exit their home jurisdictionsissuers by offering and listing their securities in other national markets, and investors by transacting in foreign exchanges or other offshore markets. Jurisdictions that find their regulatory monopolies threatened in this way may have to adjust their regulatory pricing in response to market

127. For example, Romano has repeatedly questioned the need for the SEC's mandatory disclosure regime. See Romano, supra note 97, at 93; Romano, Empowering Investors, supra note 10, at 2373; Romano, Need for Competition, supra note 10, at 465. Likewise, Choi \& Guzman doubt the promise of international cooperation in securities regulation because of concerns that national regulators might "take over" international agreements, "adding provisions and increasing the complexity of the regime to enhance the importance of the regulatory agencies.” Choi \& Guzman, supra note 11, at 915-16.

128. The ability to charge an infinitely high price will be constrained not only by market forces but also by politics. Issuers' costs of political action-for example, resort to legislative relief from overregulation by the bureaucracy-become relatively more attractive as regulatory pricing increases. So both exit and voice will serve to constrain regulatory pricing. See generally Albert O. Hirschman, EXIT, VOICE, AND LOYALTY: RESPONSES TO DECLINE IN FIRMS, ORgANIZATIONS, AND STATES (1970). 
pressures. These jurisdictions may usefully be characterized as regulatory "price-taking" jurisdictions. ${ }^{129}$

By contrast, for national markets without close substitutes-such as the U.S. market - the national regulator will continue to enjoy a healthy degree of market power. These we may characterize as regulatory "pricesetting" jurisdictions. These jurisdictions have sufficiently attractive capital markets that they can attract issuers and investors without necessarily also having to offer a particularly attractive regulatory regime. Their attractive capital markets allow them some market power. They are not subject to severe competitive pressure in terms of their regulatory pricing. Price-taking jurisdictions, on the other hand, run much greater risks that unattractive regulatory burdens will drive issuers away from their national markets to others offering more attractive pricing. ${ }^{130}$ I first discuss the United States as an exemplar of price-setting jurisdictions. Price-taking jurisdictions are discussed below in Part II.D.

\section{B. Regulatory Monopoly and Regulatory Price Discrimination}

The size and depth of the U.S. capital market enable the United States to attract issuers and investors, even if the U.S. regulatory regime is suboptimal-that is, even if the regulatory price is set too high. According to issuer choice proponents, regulators therefore have insufficient incentive to adopt more efficient regulations-which in effect would lower the price. ${ }^{131}$ But this is exactly the reason U.S. regulators will oppose competition and the choice of law rules required to bring it about. As a regulatory price-setting jurisdiction, the United States does not necessarily need to "win"-or even compete-in any international competition. Its bread-and-butter clientele-made up of U.S. issuers and investors-is largely captive. ${ }^{132}$

129. See Amir N. Licht, David's Dilemma: A Case Study of Securities Regulation in a Small Open Market, 2 TheORETICAL Inquiries L. 673 (2001). Adjustments to regulation may not be the only tool available to these jurisdictions. Competition to attract securities activity may take whatever form is useful for making the national securities market more appealing to issuers. Indirect subsidies to local underwriters, for example, might facilitate and encourage local offerings.

130. Most countries in the world fall into this latter category. These typologies of price setters and price takers are crude, of course, but distinguishing them bluntly enables us also to distinguish clearly the different incentives and constraints at work.

131. Choi \& Guzman, supra note 11, at 919.

132. "Despite the burden of compliance, avoiding the U.S. market traditionally has not made sense for U.S. issuers since the United States is the residence of a large portion of their most likely potential investors." Fox, Political Economy, supra note 19, at 770-71. Of course, if the price is exorbitant, that simply makes other alternatives relatively more attractive. For example, private placements or overseas offerings are always options, and in any event, both are likely to become more attractive over time. 
The sources of attraction of the U.S. securities market are well known. It is the largest, deepest, and most liquid market in the world, providing issuers with the largest national pool of investors. ${ }^{133}$ Having shares sold and traded in the U.S. market offers increased prestige and visibility for any issuer - for its securities and possibly for its products as well. For U.S. issuers especially, the U.S. market is likely to be the most attractive. Besides its sheer size and liquidity, the pool of U.S. investors is likely to be the cheapest source of capital for U.S. issuers, as domestic investors enjoy lower information and transaction costs than their foreign counterparts. U.S. issuers and investors share common understandings about the business and investment environment in the United States, as do local issuers and investors in most nations. They share a common language and culture. U.S. investors have natural advantages over foreign investors in terms of accessing and analyzing information about U.S. issuers. U.S. investors and their information intermediaries have better access to corporate executives and other informed sources than their foreign counterparts. ${ }^{134}$ Because of these advantages, all else equal, U.S. investors will generally be willing and able to outbid foreign investors for their stakes in U.S. firms. In addition, because the most convenient market for U.S. investors is the domestic market, U.S. issuers will wish to be there as well. U.S. issuers will naturally prefer the U.S. market to others. Their demand for access to the U.S. securities market, then, is inelastic. They have no close substitute, so the SEC enjoys market power as to them. ${ }^{135}$ "[R]esort solely to foreign capital markets for financing is not a viable option for publicly traded U.S. firms.”136

In addition, the large and liquid market will attract noncaptive issuers as well. Many of the advantages described above apply for foreign issuers as well. Whether U.S. securities laws are optimal or not, many foreign firms will still wish to issue their securities in the U.S. market. Moreover, given the assumed incentives of regulators to expand the jurisdictional reach of national securities laws and to maximize the number of firms and transactions within their regulatory purview, the SEC would seem to best pursue those ends by retaining the regulatory

133. U.S. exchanges also provide superior order execution. See Amar Bhide, Efficient Markets, Deficient Governance, HARV. Bus. REV., Nov.-Dec. 1994, at 128-29.

134. Foreign investors can and certainly do hire U.S. information intermediaries. However, all else equal, U.S. investors will also have better information on quality differences among U.S. intermediaries. See generally Stephen Choi, Regulating Investors Not Issuers: A Market-Based Proposal, 88 CAL. L. REv. 279, 290-96 (2000) (discussing benefits and risks of relying on information intermediaries).

135. This will likely remain true at least for the medium term. However, given the increasing mobility of both investors and issuers, all predictions must be tentative.

136. Romano, Empowering Investors, supra note 10, at 2397. 
monopoly it already has over domestic issuers, ${ }^{137}$ while also attempting to attract new business from those marginal issuers otherwise outside the reach of the monopoly - that is, foreign issuers. The foreign issuer is the marginal issuer with price sensitivity, so the SEC has incentive to accommodate the foreign issuer on pricing. The domestic issuer is much less price sensitive and so will not receive the same accommodation.

Differential pricing makes sense because it enables the regulator to increase the number of firms under its regulatory purview, which serves its goal of bureaucratic aggrandizement. Many foreign issuers may be unwilling to pay the regulatory price charged to U.S. issuers for access to the U.S. securities market. Without the same "hometown" attachment to the U.S. market that affects U.S. firms, foreign issuers naturally have other ready alternatives for their capital raising. Because of foreign issuers' higher elasticity of demand for access to the U.S. market, the maximizing regulator should charge them a lower price than that charged to domestic issuers. ${ }^{138}$ The regulator will price discriminate among consumers. ${ }^{139}$ Below I first explain the general conditions for price discrimination, and then describe price discrimination in U.S. securities regulation.

\section{CONDITIONS FOR PRICE DISCRIMINATION}

According to its standard economic definition, price discrimination is a strategy of nonuniform pricing through which firms with market power maximize profits. ${ }^{140}$ Translating into the regulatory realm, access to the national securities market is the "product," which the issuer purchases from the regulator by paying the specified regulatory price. We might say the regulator increases its bureaucratic "profits" when it can expand its

137. As critics of issuer choice have observed, however, even under regulatory “monopoly," issuers have choices. See John C. Coates IV, Private vs. Political Choice of Securities Regulation: A Political Cost/Benefit Analysis, 41 VA. J. INT’L L. 531, 549-53 (2001).

138. See JeAn Tirole, The TheOry of INDUSTRIAL ORGANIZATION 137 (1988).

139. Romano observes, for instance, that while the SEC is willing to lower disclosure requirements for foreign issuers in order to attract their listings to the U.S. market, it has consistently increased the disclosure requirements for domestic issuers. See Romano, Need for Competition, supra note 10, at 399. Niskanen noted the possibility that certain bureaucracies would be able to price discriminate among customers. See Niskanen, supra note 82, at 34. See generally DenNis W. Carlton \& JeFFrey M. Perloff, Modern Industrial Organization 287 (3d. ed. 1999) (discussing price discrimination); TIROLE, supra note 138, at 133-52 (same).

140. See CARlton \& PerlofF, supra note 139, at 274. 
"output"-allowing one more issuer to access the national capital market-while pricing above marginal cost for this access. ${ }^{141}$

In general, the strategy is only available if three conditions are met. First, the seller-in this case, the regulator as the seller of access to its domestic securities market-must enjoy some market power. Otherwise, any attempt to charge consumers more than a competitive price would fail. ${ }^{142}$ Second, the seller must know or be able to infer consumers' willingness to pay for each unit of the good or service at issue. In other words, the seller must be able to identify the consumers willing to pay the higher price. ${ }^{143}$ And finally, conditions must be such that arbitrage is precluded. That is, purchasers paying the lower price should not be able to resell the product. Otherwise, those paying the lower price could resell to the high-price purchasers, creating competition for the seller, driving down the price toward the nondiscriminatory monopoly price, and frustrating the seller's attempt to discriminate. ${ }^{144}$

Each of these conditions obtains for the SEC and regulators in other price-setting jurisdictions. First, as a regulator in a price-setting jurisdiction, the SEC by definition enjoys market power. Second, as for distinguishing among consumers, grouping firms into "domestic" and "foreign" serves as a useful proxy for those with low and high elasticities of demand. Securities regulators generally have no difficulty distinguishing domestic issuers from foreign. Even multinational firms typically have an identifiable "center of gravity," based on the location of their headquarters, the nationality of their executive officers and other employees, the location of their principal assets, and the like. ${ }^{145}$ The SEC definition of "foreign private issuer," for example, relies on these factors in determining which firms are sufficiently foreign so as to qualify for

141. Cf. id. (explaining incentives for price discrimination). Marginal cost may be an elusive concept in this context, as the regulator does not actually make the product. On the other hand, the character of the national market is undoubtedly shaped in some measure by the applicable securities regulation, such that the regulation itself can be considered an integral part of the product. And supplying the regulation and enforcing it as to each issuer does have costs. From that perspective, it would seem that the marginal cost of supplying the product to a foreign issuer is at least as high as for a domestic issuer, so that a lower regulatory price for foreign issuers could not be explained on the basis of lower marginal costs. Instead, reducing the price for the foreign issuer would seem a useful strategy for maximizing bureaucratic profits, provided the price still exceeds marginal cost.

142. Absent some market power, a producer faces a perfectly flat demand curve. In a perfectly competitive market, a producer that tries to charge more than the market price for its product loses all its customers to its competitors. Id.

143. See id.

144. Id.

145. See Fox, Political Economy, supra note 19, at 733. 
more lenient regulatory treatment in the United States. ${ }^{146}$ Moreover, even if some doubt existed as to the firm's "nationality," there would likely be only two contending alternatives. Regulators will not have difficulty identifying high price and low price consumers. ${ }^{147}$

Finally, as for the possibility of arbitrage, it is unlikely that a foreign firm would be able somehow to transfer its preferential access or foreign status to a domestic firm for purposes of selling securities in the domestic market. Securities regulators' careful selection of criteria for distinguishing foreign from domestic firms would preclude a foreign firm from "fronting" for a domestic firm.

\section{PRICE DISCRIMINATION IN THE UNITED STATES}

As the preceding discussion would predict, for several decades, the SEC through its rulemaking authority has reduced disclosure and other regulatory requirements for foreign issuers in the U.S. market as compared to their U.S. counterparts. ${ }^{148}$ Perhaps no single theory of regulatory behavior provides a complete explanation for this trend, but a public choice/price discrimination story is plausible.

Foreign issuers - that is, those qualifying as "foreign private issuers"149 - enjoy more relaxed requirements when it comes to offering their securities in the U.S. In a public offering, for example, their disclosure obligations concerning management compensation, material transactions, and lines of business are less stringent than for domestic

146. See infra Part II.B.2. Any corporation incorporated or organized under the laws of any foreign country qualifies as a foreign private issuer, unless both (a) more than $50 \%$ of its outstanding voting securities are held of record directly or indirectly by U.S. residents; and (b) either (i) the majority of its executive officers or directors are U.S. citizens or residents, (ii) over $50 \%$ of its assets are located in the United States, or (iii) its business is administered principally in the United States. 17 C.F.R. $§ 240.3 b-4$ (c).

147. This type of group-based discrimination is third-degree price discrimination. CARlton \& PERlOFF, supra note 139, at 280, 284. The seller has insufficient information to be able to identify each consumer's individual reservation price. Id. at 284. But the seller does have sufficient information to be able to separate consumers into groups and charge different prices to the different groups. Id. If the seller could make particularized distinctions and charge each consumer her reservation price, then that would be perfect or first-degree price discrimination. Id. at 280.

148. Alan R. Palmiter, Toward Disclosure Choice in Securities Offerings, 1999 Colum. Bus. L. REV. 1, 44-54 (enumerating various reduced regulatory hurdles for foreign issuers). Curiously, Howell Jackson characterizes this trend as a sort of "Delawarization" of securities law. Howell E. Jackson, Centralization, Competition, and Privatization in Financial Regulation, 2 TheORETICAL InQUIRIES L. 649, 658 (2001). While these SEC rules relax U.S. regulatory requirements for foreign issuers, they hardly facilitate free choice.

149. See supra note 146 . 
issuers. ${ }^{150}$ In adopting special, less demanding public offering registration forms for use only by foreign issuers, the SEC expressly recognized that "imposition on foreign issuers of the same disclosure standards applicable to domestic issuers could discourage offerings of foreign securities in the United States." ${ }^{\prime 151}$ Foreign issuers also enjoy easier access to private U.S. capital markets under Rule 144A than their domestic counterparts. ${ }^{152}$ Their offshore offerings under Regulation $\mathrm{S}$ are not subject to the same restrictions that apply to U.S. issuers. ${ }^{153}$ Foreign issuers additionally enjoy special exemptions related to cross-border tender offers, business combinations, and rights offerings. ${ }^{154}$ They enjoy special accommodation from the SEC with respect to scheduling needs and confidential treatment of filings. ${ }^{155}$

Foreign issuers are also exempt from many of the rules to which domestic issuers are subject when they list shares on a national securities exchange. ${ }^{156}$ Foreign issuers are exempt from most of the proxy rules. ${ }^{157}$

150. See Adoption of Foreign Issuer Integrated Disclosure System, Securities Act Release No. 6437, SEC Docket (CCH), at 964 (Nov. 19, 1982) (adopting Forms F-1, F-2, and F-3 in extending integrated disclosure to foreign issuers).

151. Integrated Disclosure System for Foreign Private Issuers, Securities Act Release No. 6360, 24 SEC Docket (CCH), at 3, 4 (Nov. 20, 1981) (proposing forms F-1, F-2, and F-3). In weighing the public interest, the SEC characterized reduced disclosure for foreign issuers as beneficial insofar as it expanded investment opportunities for U.S. investors. See id.

152. Rule 144A allows for resale of restricted securities to qualified institutional buyers. See 17 C.F.R. $\S 230.144$ A (2002). However, the benefits of Rule 144A for domestic issuers are limited by the fact that it is unavailable with respect to any class of security that is traded on a U.S. public market. See id. Domestic issuers would therefore be unable to issue common stock to institutional investors in reliance on Rule 144A. Foreign issuers, by contrast, are much less likely to be affected by this restriction. Even a foreign issuer whose common stock is publicly traded on a major foreign exchange may issue common stock in the United States to qualified institutional buyers under 144A, as long as its stock is not also listed on a U.S. exchange or NASDAQ.

153. See Rule 903(b)(3), 17 C.F.R. § 230.903(b)(3); Rule 905, 17 C.F.R. § 230.905; see also supra notes 39-55 and accompanying text (discussing Regulation S).

154. See Cross-Border Tender and Exchange Offers, Business Combinations, and Rights Offerings, Securities Act Release No. 7,759, Exchange Act Release No. 45,054, [1999-2000 Transfer Binder] Fed. Sec. L. Rep. (CCH) ๆ 86,214 at 82,536 (Oct. 26, 1999).

155. See EdWARD F. GREENE, ET AL., 1 U.S. REgUlATION OF THE INTERNATIONAL SECURITIES AND DERIVATIVE MARKETS, at 2-45 n. 45 (1999).

156. These rules are promulgated by the SEC pursuant to its authority under the Exchange Act. 15 U.S.C. §§ 78a-78bbbb.

In general, an issuer without publicly listed shares is also required to register under the Exchange Act and be subject to Exchange Act rules if its assets exceed \$10 million and it has a class of equity security with at least 500 holders of record. See supra note 55. However, a foreign private issuer without publicly listed shares is exempt from Exchange Act registration and rules if it has no class of equity with more than 300 holders resident in the United States, or if it furnishes to the SEC the disclosure information provided in its home jurisdiction. 17 C.F.R. $\S \S 230.12$ g3-2(a) to (b). 
Foreign issuers and their insiders are excused from the reporting obligations and short-swing profit rules under Section 16 of the Securities Exchange Act of $1934 .{ }^{158}$ Their periodic disclosure obligations are less stringent than those applied to domestic issuers. For example, foreign issuers file annual reports on Form 20-F, the requirements of which are somewhat less demanding than the annual reporting requirements applicable to domestic issuers. ${ }^{159}$ Foreign issuers are excused from filing 10 -Qs, the quarterly disclosures that apply to domestic issuers. ${ }^{160}$ In addition, the SEC has recently proposed to relieve foreign issuers from the current requirement of having to reconcile their financial statements to U.S. generally accepted accounting principles (U.S. GAAP). Foreign issuers would instead be permitted to do their financial reporting under international accounting standards promulgated by the International Accounting Standards Committee (IASC), ${ }^{161}$ which are less demanding than U.S. GAAP. ${ }^{162}$

Domestic issuers might certainly gripe about this differential treatment. However, given their inelastic demand for access to the U.S.

157. 17 C.F.R. § 240.3a12-3.

158. Id.

159. See Jackson \& Pan, supra note 32, at 666. In addition, a foreign private issuer has six months after the end of its fiscal year to file its 20-F report, whereas the quarterly and annual reports due from domestic issuers must be filed within three months after the end of the fiscal quarter or year. The requirements of Form 20-F conform to international disclosure standards adopted by IOSCO. International Disclosure Standards, Securities Act Release No. 33-7745, 70 SEC Docket (CCH) at 1993 (Sept. 28, 1999) (adopting release); International Disclosure Standards; Correction, Securities Act Release No. 33-7983, 75 SEC Docket (CCH) at 522 (June 11, 2001) (correction).

160. 17 C.F.R. § 240.3a12-3. Instead, a foreign private issuer reports on Form 6$\mathrm{K}$, which contains information which has been made publicly available in the home jurisdiction. Id. § 230.13a-16. This information is not considered "filed" and is therefore not subject to Exchange Act liability for the filing of false or misleading documents with the SEC. Hal S. Scott \& Philip A. Wellons, International SECURities Regulation 28 (2002).

161. International Accounting Standards, Securities Act Release No. 33-7801, 71 SEC Docket (CCH) at 1551 (Feb. 16, 2000). In 2000, the IASC was restructured as the International Accounting Standards Board (IASB). See International Accounting Standards Board, Restructuring IASC (1997-1999), at http://www.iasc.org.uk/cmt/ 0001.asp?s $=1093928 \& \mathrm{sc}=\{\mathrm{C} 4 \mathrm{~B} 840 \mathrm{~A} 7-\mathrm{C000}-4252-8 \mathrm{AC6}-579 \mathrm{E} 55482 \mathrm{~F} 7 \mathrm{~F}\} \& \mathrm{n}=91 \quad$ (las visited Jan. 18, 2003).

162. The fate of the proposal is unclear. Some analysts believe U.S. issuers will oppose, since the move allows their foreign competitors the benefit of lower standards. However, a similar push by the NYSE to relieve foreign issuers of the burdens of U.S. GAAP reconciliation has generated no discernible opposition from large U.S. issuers. See infra note 233 and accompanying text. Other opposition may also surface from those opposed to lower accounting standards generally. The fear is that U.S. issuers may push to use the same lower standards. See Romano, Need for Competition, supra note 10, at 398 n.30. 
market, local issuers are more or less territorially bound. Regulators are therefore free to some extent to ignore the desires of their "captive" consumers. There are limits to the degree of discrimination, of course. As discrimination increases to the disadvantage of domestic issuers, the costs of political action to remedy the discrimination become relatively more palatable, an issue I discuss below. ${ }^{163}$

\section{Issuer Choice?}

The preceding discussion suggests that in the strongest securities markets, national regulators bent on bureaucratic aggrandizement will pursue a strategy of regulatory price discrimination. Playing issuer choice, however, would make no sense, at least if we credit the assumptions of issuer choice proponents concerning regulators' incentives. On this view, regulators' desire for bureaucratic aggrandizement will cause them to overregulate-i.e., impose regulation exceeding the regulatory ideal for each firm. ${ }^{164}$ Therefore, a move from the current mandatory territorial system to issuer choice would likely result in a number of issuers figuratively "fleeing" from U.S. regulation to lower cost regulatory regimes. Issuer choice would allow issuers to escape the overzealous regulation of the SEC while continuing to issue and list their securities in the United States, effectively breaking the SEC's regulatory monopoly. ${ }^{165}$

Assuming regulators' incentives are as issuer choice proponents say, we have to conclude that regulators in price-setting jurisdictions would oppose competition and rules creating a competitive framework. More likely, the rational regulator will strive to preserve her monopoly and pursue a price discrimination strategy. ${ }^{166}$ Under the current territorial

163. See infra Part III.B.3.

164. See supra note 83 and accompanying text.

165. Jack Coffee has questioned this assumption of issuer choice proponents that regulators necessarily overregulate. Instead, Coffee identifies a trend suggesting that strong regulation may attract issuers, rather than repel them. He argues that foreign firms cross-list in the U.S. in order to bond themselves to high disclosure standards that protect minority shareholder interests. Listing in the U.S. serves as a commitment device that attracts investors and improves firm values. See John C. Coffee, Jr., Racing Towards the Top?: The Impact of Cross-Listings and Stock Market Competition on International Corporate Governance, 102 CoLUM. L. REV. 1757 (2002).

166. Some scholars have argued that even if the leaders of the bureaucracy espouse these self-aggrandizing goals, lower level employees will have no stake in achieving these ends, and agency and transaction costs within the bureaucracy will preclude their attainment. This organizational behavior literature predicts lethargy and unresponsiveness to either public or private interests. See, e.g., Donald C. Langevoort, The SEC as a Bureaucracy: Public Choice, Institutional Rhetoric, and the Process of Policy Formulation, 47 WASH. \& LEE L. REV. 527 (1990). 
system, price-setting national regulators need only compete for marginal foreign issuers, for whom the regulatory "full price" may be too high. At the same time, regulators may maintain their monopolies over captive domestic issuers. The SEC's current program to ease disclosure and other requirements for foreign issuers is consistent with this strategy.

\section{Price-Taking Jurisdictions}

Price-taking jurisdictions face a different set of constraints and opportunities from price setters. However, regulators in price-taking jurisdictions are no more likely to pursue issuer choice than in pricesetting jurisdictions.

Price-taking jurisdictions will be those with relatively smaller, less liquid, less attractive capital markets. For foreign and perhaps even local issuers, the small local capital market has many possible substitutes, so issuers will be price sensitive. Such jurisdictions face high demand elasticity and are susceptible to price competition from other jurisdictions. Even local companies may have no strong incentive to issue securities locally if the regulatory regime is inhospitable. Therefore, price takers must take care to assure they do not lose "business" by regulatory mispricing of access to their capital markets. Regulators will have a more difficult time pursuing both goals of augmenting their securities bureaucracies and also maximizing the volume of local securities offerings and trading. Unlike their counterparts in the largest national markets, regulators in price-taking jurisdictions will feel strong pressure to lower their regulatory prices in order to maximize the volume of local securities activity to preserve the local industry.

Regulators may therefore have little leverage to negotiate reciprocal recognition arrangements with other states. They may have no choice but to lower regulatory hurdles unilaterally or to offer unilateral recognition of foreign regulatory regimes. This strategy forswears application of national regulation to firms issuing or listing in the national market, but it at least facilitates securities activity within the jurisdiction to preserve the

On the other hand, if survival of the bureaucracy is at stake, it is far more likely that all participants in the bureaucracy would band together for the common goal of preserving the organization. The goals of the head bureaucrats would faithfully be pursued by the rank-and-file. See Jonathan R. Macey, Administrative Agency Obsolescence and Interest Group Formation: A Case Study of the SEC at Sixty, 15 CARDOzo L. REV. 909, 917-18 (1994). Asking the SEC to give up its territorial regulatory jurisdiction-as issuer choice does - might be perceived as a life-and-death struggle.

In any event, proponents of issuer choice assume that governments will be responsive to external stimuli, an assumption I am content to indulge. This indulgence, however, hardly points to the emergence of a framework conducive to the regulatory competition envisioned by issuer choice advocates. 
viability of the national market itself. ${ }^{167}$ And if the regulatory agency is reluctant to give up its regulatory jurisdiction, pressure from the securities industry may cause national lawgivers to act instead.

Israel's recent history provides one salient example. Until recently, many Israeli high-tech firms listed their shares on the NYSE without also listing with the Tel Aviv exchange. U.S. disclosure requirements for foreign issuers are different from, and in some areas less stringent than, Israeli disclosure rules. ${ }^{168}$ These Israeli firms avoided the costs of complying with Israeli securities law simply by not listing in Israel. As part of an effort to win back listings, the Knesset, Israel's legislature, recently changed its law to provide for unilateral recognition of U.S. securities laws, effectively exempting Israeli firms already in compliance with U.S. disclosure rules. The Israeli Securities Agency (ISA) had not provided such an exemption. It fought the legislative change along various dimensions, but was ultimately unsuccessful. The Knesset chose to favor the local securities industry over the ISA's pleas for more stringent regulation. ${ }^{169}$

That regulators in price-taking jurisdictions lack market power, however, does not imply that they would prefer issuer choice. By definition, price takers are forced by market pressures to take the regulatory price set by price-setting jurisdictions. They may have to accord recognition to the regulatory regimes of particular jurisdictions. But this does not suggest that price takers need offer blanket recognition to whatever securities regime an issuer might choose. Moreover, the interaction of price takers with price setters suggests that even wholesale recognition by price takers would not create the competitive regime envisioned by issuer choice proponents. Regulators in price-setting jurisdictions will not feel the market pressure that affects price takers. The market power of the one and the lack of market power of the other guaranty that recognition will only go in one direction. Israel may be forced to accord recognition to U.S. law, but the United States feels no similar pressure to allow local securities activities of issuers regulated solely under Israeli law.

167. See Amir N. Licht, Stock Exchange Mobility, Unilateral Recognition, and the Privatization of Securities Regulation, 41 VA. J. INT'L L. 583, 596-98 (2001) (describing unilateral recognition strategy of small to medium-sized stock exchanges in smaller capital markets); Cally Jordan, Regulation of Canadian Capital Markets in the 1990s: The United States in the Driver's Seat, 4 PAC. RiM L. \& POL’Y J. 577, 596 (1995) (describing Canada's proposed strategy of regulatory "free-riding”).

168. See Amir N. Licht, Managerial Opportunism and Foreign Listing: Some Direct Evidence, 22 U. PA. J. INT’L ECON. L. 325, 338 (2001).

169. See id. at 340-41. Roberta Romano also recognizes regulators' disincentives to promote competition, especially regulators from smaller markets. See Romano, Need for Competition, supra note 10, at 390-400. 


\section{INTEREST GROUPS AND INTERNATIONAL COOPERATION}

Regulators are of course not the only actors affecting the development of international securities regulation. Legislative and executive action would likely be required to bring about the international cooperation necessary for an international issuer choice system. More generally, legislators and executives exercise oversight over the structure of national securities regulation and the interface among national regulatory regimes. Unlike securities regulators, however, legislators and executives are unlikely to hold strong personal preferences regarding the structure of international securities regulation. They lack the personal stake that regulators have. ${ }^{170}$ Its technical nature and its low visibility and salience for the general public ordinarily make securities regulation a difficult area around which to rally popular opinion. ${ }^{171}$ Instead, we can expect any reforms to turn on a struggle among the various interests of the informed and concentrated few. ${ }^{172}$ In the United States, besides the obvious influence of the SEC, securities lawyers, other industry professionals, and corporate interests are likely to weigh in on any proposal to effect a major shift in the choice of law rules for U.S. securities law.

The importance of interest groups in domestic politics has been recognized for some time. ${ }^{173}$ However, in international politics, influential scholars have long been content to treat states as black boxes

170. Rational legislators may delegate to agencies to avoid blame for the costs of regulation, while also being able to claim credit for its benefits. See MORRIS P. FIORINA, CONGRESS: Keystone of THE WASHINGTON Establishment 39-49 (1977); Morris P. Fiorina, Legislator Uncertainty, Legislative Control, and the Delegation of Legislative Power, 2 J.L. ECON. \& ORG. 33 (1986).

171. Moreover, as recent events have suggested, a spectacular securities fraud case might galvanize public opinion in favor of more stringent regulation. See, e.g., Enron Fallout: Public Policy Consequences of Enron's Collapse, 34 Sec. Reg. \& L. Rep. (BNA) No. 9 (Mar. 4, 2002) (discussing likely regulatory reforms in securities, accounting and auditing, corporate governance, and pension areas, among others, following the demise of Enron). It is more difficult to imagine a similar spellbinding example of costly overregulation that spurs public outrage and ensuing securities deregulation.

172. See Sam Peltzman, Toward a More General Theory of Regulation, 19 J.L. \& ECON. 211 (1976); George J. Stigler, The Theory of Economic Regulation, 2 BELL J. ECON. \& Mgmt. Sci. 3 (1971). See generally Mancur Olson, The Logic of Collective ACtion: Public GoOds AND the THEORY Of GROUPS (1965).

173. See, e.g., James M. Buchanan \& Gordon Tullock, The Calculus of Consent: Logical Formulations of Constitutional Democracy (1962); Olson, supra note 172. 
or "billiard ball[s],", viewing states as rational unitary actors with stable and broadly similar domestic preferences. Under this approach, domestic politics matters little if at all. "[T]he internal attributes of [states] are given by assumption rather than treated as variables."175

The methodological individualism of rational choice theory, however, has found its way into international political discourse. Nuanced models of state behavior look through the state to the underlying interests of individuals and interest groups that influence international affairs. ${ }^{176}$ Scholars of political economy use "two-level" games to model this relation between domestic influences and international relations. ${ }^{177}$ Domestic politics matters for international policy, and unitary actor models of state behavior run the risk of missing important domestic causal variables that affect international policy. ${ }^{178}$

174. Andrew Moravcsik, Introduction: Integrating International and Domestic Theories of International Bargaining, in DOUBLE-EDGED DiPLOMACY: INTERNATIONAL BARgAining AND Domestic Politics 5 (Peter B. Evans et al. eds., 1993).

175. Robert O. Keohane, Theory of World Politics: Structural Realism and Beyond, in NeO-REALISM AND ITS CRITICS 165 (Robert O. Keohane ed., 1986).

176. The longstanding realist tradition of treating states as unitary actors may be justifiable in national security contexts. If national survival is truly at stake, then one might plausibly assume all groups within the nation could unite to pursue the singular goal of survival. However, this simplifying assumption becomes less useful when commercial and economic relations are at issue, since domestic factionalism is likely to matter a great deal. See Robert O. Keohane, After Hegemony: Cooperation and Discord in the WORLD POLITICAL ECONOMY 29 (1984).

177. See Robert D. Putnam, Diplomacy and Domestic Politics: The Logic of TwoLevel Games, 42 INT'L ORG. 427 (1988); see also DOUBle-EDged DiplOMACY: International Bargaining and Domestic Politics, supra note 174; Helen V. Milner, InTERESTS, Institutions, AND InfORMATION: Domestic Politics AND InTERnATIONAL Relations (1997); Jonathan R. Macey, Chicken Wars as a Prisoners' Dilemma: What's in a Game?, 64 Notre DAME L. ReV. 447, 448 (1989) (reviewing JoHn A.C. CONYBEARE, Trade Wars: The Theory and Practice of InTERnational Commercial Rivalry (1987)) (noting importance of public choice analysis in understanding trade policy formation).

178. See Keisuke Iida, When and How Do Domestic Constraints Matter?: TwoLevel Games with Uncertainty, 37 J. CONFLICT RESOL. 403, 403-04 (1993) (criticizing the realist tradition of "treat[ing] nation-states as unitary actors," and noting that "[i]n reality, foreign policy decisions are the result of political processes within nation-states"); Moravcsik, supra note 174, at 4; Duncan Snidal, Coordination versus Prisoners' Dilemma: Implications for International Cooperation and Regimes, 79 AM. Pol. ScI. REV. 923, 925-26 (1985) (acknowledging drawbacks to realist assumption "[t]reating states as goal-seeking actors with well-defined preferences"). Moreover, speaking of states' interests and states' preferences may be anthropomorphic: "Institutions in general, and governments in particular, do not have preferences, people do. Governmental policy reflects the preferences of powerful constituents, not some mystically determined set of preferences that might be described as the 'national interest.'” Colombatto \& Macey, supra note 59, at 931-32; see also Erin A. O’Hara \& Larry E. Ribstein, From Politics to Efficiency in Choice of Law, 67 U. CHI. L. REV. 1151, 1169 (2000) (criticizing traditional 
Domestic politics matters because the state is not a unitary actor. Groups within it have different policy preferences because they are differentially affected by government policies. Any change in policies, as might occur because of international cooperation, has domestic distributional and electoral consequences. These domestic consequences are the "stuff" of politics. ${ }^{179}$

In this Part, I consider interest groups and the international cooperation that would be necessary to implement issuer choice. My discussion focuses primarily on the U.S. context and price-setting jurisdictions. I first discuss likely interest group alignments that would frustrate achievement of international issuer choice agreements. ${ }^{180}$

The discussion in the preceding Part suggests that regulators will be an important interest group in their own right. Given their assumed incentives of bureaucratic aggrandizement, they will prefer regulatory price discrimination to issuer choice. Moreover, several features of the existing structure of domestic and international securities regulation suggest that securities regulators will dominate any endeavors toward international regulatory coordination. Regulators have significant informational and other advantages over legislators and executives who would attempt to oversee their regulatory activities. In addition, I show below the likely absence of any domestic interest group unambiguously committed to issuer choice. This further reduces its likelihood.

Identification of regulatory price discrimination as a plausible strategy for regulators in price-setting jurisdictions is important to the ensuing interest group analysis because it more realistically describes the political and policy alternatives for the various interested groups than have previous commentators. To the extent issuer choice advocates have discussed the politics of issuer choice, they have tended to pose the policy

emphasis on government interests, as opposed to individual interests, in U.S. conflicts scholarship and court opinions).

179. MiLNER, supra note 177, at 16.

180. One must necessarily speak in terms of probabilities as opposed to proofs in attempting to forecast interest group alignments, especially in the international context. As Andrew Guzman has noted:

The difficulty in applying public choice to normative analyses . . . is that the outcome of interest group politics is very difficult to predict. It is, therefore, difficult to construct a model of government decisionmaking-even if one focuses on relatively well-defined areas of law such as antitrust or securities. Once one adds an international dimension to the problem, the task is even more difficult.

Guzman, supra note 33, at 902 (citation omitted). 
alternatives in stark contrast. Private choice reform is contrasted to the status quo of mandatory disclosure, which is characterized as a monolithic endeavor by regulatory monopolists to force rules upon recalcitrant issuers. Identification of the price discrimination strategy suggests that regulators may be more responsive to market pressure and to pressure from interested groups than the standard regulatory monopolist description implies. ${ }^{181}$ This responsiveness tends to undermine not only claims concerning the inefficiency of the status quo, but also issuer choice advocates' implicit assertion that interested groups exist that would prefer issuer choice.

A lack of interest group support is not the only obstacle to issuer choice cooperation. As with securities regulation generally, international agreements concerning regulatory jurisdiction would necessarily be technical, complex affairs. Detailing, monitoring, and enforcing commitments would be difficult, and this difficulty would likely discourage commitment ex ante. This is especially damaging for the prospects for issuer choice. Regulatory price discrimination is the status quo. Without useful international agreements, no reform-whether issuer choice or some other approach — can emerge.

I first explain regulators' unique role as the dominant interest group in any international undertaking for regulatory coordination. I then discuss other interest groups, their various stakes in promoting or opposing issuer choice versus regulatory price discrimination, and their likely influence on national policymakers. Finally, I note the demands of international coalition formation and the effects of complexity and ambiguity in achieving international cooperation. Along with the two possible approaches of issuer choice and regulatory price discrimination, I also consider harmonization. I ultimately conclude that of these three, issuer choice is the least likely to arise.

\section{A. Regulators’ Dominant Role in International Securities Regulation}

Given the highly detailed and technical nature of securities regulation, regulators will have significant informational advantages over legislators and executives, who ordinarily have little incentive to devote resources to monitoring regulators or educating themselves about regulators' activities. ${ }^{182}$ In the even narrower area of international

181. John Coates makes a similar point regarding SEC responsiveness to issuers. See Coates, supra note 137, at 553.

182. "Although the nominal relation of a bureau and its sponsor is that of a bilateral monopoly, the relative incentives and available information, under most conditions, give the bureau the overwhelmingly dominant monopoly power." NISKANEN, supra note 82 , at 30 . 
securities regulation, which requires some knowledge of regulatory practices in foreign jurisdictions, regulators' informational advantage is overwhelming. Without some way of ameliorating this information deficit, legislators and executives will be in a poor position to initiate any change that regulators oppose. Regulators' opposition may therefore be fatal for issuer choice. ${ }^{183}$

Informed interest groups may assist policy makers in overcoming information deficits. ${ }^{184}$ However, as I describe below, it is unlikely-at least in regulatory price-setting jurisdictions-that any interest group will emerge that unambiguously supports issuer choice. Without an interest group champion with sufficient interest and resources to counter regulators' informational superiority, the prospects for issuer choice are bleak. ${ }^{185}$

Absent support of important interest groups, national lawmakers will likely be reluctant to back issuer choice over regulators' opposition. Politicians are risk averse, and a move to issuer choice presents uncertainty. Politicians will be reluctant to assume publicly the responsibility for the uncertain outcomes resulting from the broad deregulation of securities markets that issuer choice would entail. ${ }^{186}$ Even assuming the improved capital market efficiency that issuer choice proponents claim would result, that outcome is not sexy. Certain interested groups might understand and appreciate this result in the abstract, but it is difficult to measure or demonstrate in the short run, and might not be salient to the general public. ${ }^{187}$ The downside political risk

183. See Anne M. Khademian, The SEC and Capital Market Regulation: The Politics of ExPERTISE 188 (1992) (describing virtual veto power of SEC as to legislation it opposes).

184. See MiLner, supra note 177, at 23 (“[T] he 'solution' to the information problem of legislatures is to depend on informed interest groups.”).

185. See id. at 22 (asserting necessity of at least one interest group to endorse policy as to which legislature suffers information deficit).

186. See KHADEMIAN, supra note 183, at 12 (describing risk aversion of legislators with respect to securities policy).

187. This is not to say that deregulation may never result from widespread public indignation and in the face of interest group opposition. See Michael E. Levine \& Jennifer L. Forrence, Regulatory Capture, Public Interest, and the Public Agenda: Toward a Synthesis, 6 J.L. ECON. \& ORG. 167, 168 (1990) (discussing importance of "public agenda" in reducing political slack, which otherwise enables regulators to favor private interests). Deregulation has occurred in securities and other industries, but is typically a result of changing economic conditions and shifting interest group alignments. One famous instance of securities deregulation was the abolition of the NYSE's fixed commission structure with the Securities Acts Amendments of 1975, Pub. L. No. 94-29, 89 Stat. 97, 107 (1975). However, this deregulatory moment is not inconsistent with interest group theories of regulation. Though the NYSE was a powerful opponent of deregulation of fixed commission rates, the rise of institutional investors created a powerful counterweight to NYSE influence. Moreover, institutional investors' increasing 
seems greater. A loss of investor confidence, perhaps followed by a market downturn, would not only hurt private interests. It would also put securities deregulation on the "public agenda," 188 drawing negative attention from the general public and damaging the political fortunes of any sponsoring lawmakers.

Incremental moves in the direction of private choice-as opposed to wholesale adoption overnight—could of course reduce the scope of legislative uncertainty. For instance, the United States could first agree with Canada that both countries' issuers could avail themselves of either country's securities regime. ${ }^{189}$ And then either or both could reach a similar agreement with the United Kingdom. ${ }^{190}$ But even this incremental approach may be fraught with uncertainty. Even with the limited recognition of disclosure systems between the United States and Canada under MJDS, ${ }^{191}$ dissatisfaction with Canadian enforcement recently

ability to avoid fixed commissions by trading on regional exchanges and over the counter also put competitive pressure on fixed commissions, making their abolition less drastic a change than it might otherwise appear. See SusAn M. Phillips \& J. Richard ZeCher, The SEC AND the Public InTerest, at ch. 4 (1981). Ideologically driven deregulation may occur in the face of opposition from concentrated groups. However, this phenomenon apparently occurs primarily where expert consensus strongly-perhaps uniformly - supports deregulation, which is not the case here. See MARTHA DeRTHICK \& Paul J. Quirk, The Politics of Deregulation (1985) (discussing pro-competitive deregulation in the airline, trucking, and telecommunications industries in the 1970s and early 1980s, which occurred despite powerful industry support for regulatory protection).

188. See Levine \& Forrence, supra note 187, at 191-92.

Those not specially affected by regulatory information do not ordinarily invest in acquiring it.

However, at any given time in any given polity, there is a small set of issues that has become the object of intense public attention. These issues are very widely attended to. They are covered in virtually every issue of every printed news medium, and are reported on constantly by the broadcast media. These issues pervade the information atmosphere. . . . Let us call the set of these issues the "public agenda."

Id.

189. Canada and the United States have implemented MJDS, a system of mutual recognition for their respective disclosure rules. See supra note 79 and accompanying text. While MJDS allows qualifying companies of both countries to rely on their home country disclosures to issue securities in the other jurisdiction, it does not affect issuer choice. It does not permit a U.S issuer to select application of Canadian disclosure rules or vice versa.

190. A shared language and business culture with the United States make Canada and the United Kingdom the most promising candidates for a nascent issuer choice arrangement with the United States. Cf. Scott, supra note 52, at 84 ("The United Kingdom would be a logical candidate for the MJDS extension, given its shared AngloSaxon tradition and English language with the United States and Canada.”). Apparently, at some point, the United Kingdom was considered a prime candidate for expansion of MJDS. See id. at 85.

191. See supra note 75 and accompanying text and notes 189-90. 
caused the SEC to consider eliminating the program. ${ }^{192}$ While the Ontario Securities Commission's responsiveness to the SEC's concerns seems to have preserved the program for the time being, ${ }^{193}$ the experience illustrates the difficulty of predicting ex ante how cross-border recognition of securities law may play out. ${ }^{194}$ In addition, it further emphasizes the critical role of regulators in monitoring and managing cross-border cooperative arrangements on securities regulation.

Another factor that will tend to inhibit politicians from embracing issuer choice absent interest group support is their short time horizons. ${ }^{195}$ Even if issuer choice were ultimately to produce net benefits to society, the timing of the realization of the potential costs and benefits would dissuade politicians from backing it. Issuer choice advocates acknowledge the probable switching costs involved with its implementation. ${ }^{196}$ An initial period of confusion would ensue, as issuers, investors, and regulators sorted out the myriad details of integrating foreign securities rules for local securities transactions. It seems likely that over time, a handful of regimes would predominate in any given national market, such that the menu of probable choices would become manageable and scale economies could be realized. ${ }^{197}$ In the meantime, though, a real possibility would exist of a market hiccup or dramatic scandal that could be linked to issuer choice deregulation.

The problem for politicians is that switching costs are borne largely in the short run, while the claimed benefits of issuer choice would accrue, if at all, in the long run. As earlier noted, the general public would be unable to appraise immediately the claimed long-run efficiency advantages, which would emerge only over time. ${ }^{198}$ But electoral politics

192. See Scott, supra note 52, at 82 (describing SEC dissatisfaction).

193. See Eric Reguly, To the Point: OSC Deserves Credit for Saving Threatened Access to U.S., Globe \& MAIL, Jan. 18, 2001, at B10 (describing Ontario Securities Commission improvements in disclosure enforcement responding to SEC pressure).

194. For further discussion of indeterminacy in international securities regulatory cooperation, see infra Part II.C.2.

195. See Paul Pierson, Increasing Returns, Path Dependence, and the Study of Politics, 94 Am. Pol. ScI. Rev. 251, 261 (2000).

196. See Choi \& Guzman, supra note 11, at 924-27 (discussing possibility of information overload from issuer choice and possible remedial measures).

197. See id.

198. In the short run under issuer choice, in the best case, issuers in the United States might choose more lax regulation because U.S. law is too burdensome. But that would merely highlight for the public the weaknesses of the U.S. regulatory regime. This might prove satisfying for issuer choice advocates, but it is not clear that any legislators would end up looking good. Why were the securities laws so burdensome in the first place? In the worst case, if issuers chose more lax regulation to commit fraud or behave opportunistically toward security holders, U.S. investors would suffer, and legislators would surely look bad. I am indebted to Jill Fisch, Professor of Law, Fordham University 
forces elected officials to discount the future severely. A politician who must stand for re-election every few years will prefer policies with discernible short-term payoffs, with less regard for long-term effects that occur in the next election cycle. Any long-term benefits will generally accrue to the political benefit of some other politician. ${ }^{199}$

In the end, issuer choice is not a reform to which legislators will naturally be attracted without interest group support. The potential benefits are politically murky and not easily realized in the short term; the possible costs are politically salient-hardly an appealing policy prescription for risk averse politicians. In addition, regulators will enjoy significant information advantages over elected officials with respect to international securities regulatory policy. Regulators' opposition to issuer choice, then, will be a significant impediment to its adoption.

\section{B. Interest Groups}

As noted above, interest group involvement could theoretically overcome politicians' reluctance and information deficit with respect to issuer choice. ${ }^{200}$ How would various interest groups line up as between a price discrimination approach - a plausible characterization of the status quo-and issuer choice reform? It would appear that several important groups would oppose issuer choice but none would unambiguously support it. Those with significant investments in the status quo-either human capital investments or investments in institutional structureswould support regulatory price discrimination and oppose a move to private choice. In particular, regulators and those paid to advise issuers concerning regulation-primarily securities lawyers and accountantscould be expected to oppose vigorously any move toward international issuer choice. Securities firms and exchanges might theoretically be attracted to the increased volume of securities activity that issuer choice promises. However, these groups also have large stakes in the current U.S. regulatory structure, including built-in informational advantages over other market participants. Moreover, regulatory price discrimination can increase securities volume as well, without the disruption that would attend a switch to private choice.

School of Law and Director, Fordham Center for Corporate, Securities, and Financial Law, for this observation.

199. Interest groups with long-term stakes in an issue might be able to persuade politicians to adopt longer time horizons. However, it is unclear whether any such interest group exists with respect to issuer choice. See infra Part III.B.

200. See supra notes 184-85 and accompanying text. 
The group left out of this rent fest, of course, is domestic issuers. They are more or less tied to the U.S. market. ${ }^{201}$ Lower regulatory standards for foreign issuers can only harm domestic issuers by lowering foreign rivals' costs of capital, placing domestic issuers at a competitive disadvantage. However, opposition to regulatory price discrimination would not likely drive issuers to support private choice. Harmonization may be issuers' favored approach.

I elaborate on these analyses below.

\section{LAWYERS AND ACCOUNTANTS}

As already noted, maximizing regulators would not want to have to compete for a market that they have already captured. Lawyers and accountants will share similar incentives with regulators. With their expertise in national securities law, lawyers have significant undiversifiable human capital investments that are more or less territorially bound. Accountants will possess similar territorially-bound expertise concerning U.S. GAAP and financial disclosure requirements under U.S. securities law. In that sense, these groups benefit from the national regulatory monopoly as much as regulators do. They should therefore support the existing territorial system, as well as regulators' attempts to expand the reach of national law by attracting foreign issuers through price discrimination.

U.S. lawyers' stock in trade, for example, is their ability to advise with respect to U.S. law. U.S. lawyers are expert in crafting disclosure documents for their client firms subject to the securities laws. Corporate and plaintiffs'-side securities lawyers are expert at litigating class actions under the complex liability and procedural rules peculiar to the U.S. regime of private enforcement. For their part, U.S. accountants have developed expertise in producing and auditing the complex and detailed financial statements required of issuers under U.S. securities laws, ${ }^{202}$ as well as expertise in avoiding the possible securities fraud liability that may follow an accounting misstep. ${ }^{203}$

201. See supra note 132 and accompanying text. While domestic issuers might be able to issue new securities in overseas markets, their existing listings in the United States subject them to the U.S. disclosure apparatus. Delisting locally is unlikely to be a useful alternative, at least in the near term.

202. Regulation S-X describes the accounting rules applicable to SEC filings and the audited financial statements required under the Securities Act and the Exchange Act. See 17 C.F.R. §§ 210.1-01 to .12-29.

203. See HAZEN, supra note 34, § 9.6 (describing SEC auditing and accounting requirements). 
Under an issuer choice regime, there is a high probability that demand for all this expertise would decline. Most analysts agree that U.S. disclosure requirements are among the most stringent in the world. If as commonly assumed among issuer choice advocates, this level of disclosure is suboptimal for some nontrivial percentage of firms, then the demand for U.S. securities lawyers' and accountants' expertise would likely decline. Issuers may choose to issue in the United States, but under the less stringent disclosure obligations of other nations. In that case, the volume of securities sold and traded within the United States would probably rise, while the number of issuers subject to U.S. disclosure rules would not, and may in fact decline. The armies of private lawyers, accountants, and other professionals who produce corporate disclosure documents would see no benefit in the increased volume of securities activity in the United States. ${ }^{204}$

More generally, lawyers' and accountants' livelihood would depend to a great extent on the outcome of the competition for law. If one's home country law turned out not to be popular among issuers, the demand for legal and accounting expertise would decline, and their professional and financial fortunes would suffer. Among those invested in the current regime of U.S. securities regulation, besides the SEC, private securities lawyers and accountants have perhaps the largest stake in maintaining the status quo-including further steps in the direction of price discrimination-and opposing issuer choice.

A few qualifications to the above analysis may be in order. Individual lawyers and accountants could possibly attempt to remedy the territorial limits of their expertise by diversifying their human capital and developing expertise in the securities laws and accounting rules of other jurisdictions besides their home countries. However, given differences in language, culture, and business practices, as well as the complexity and nuance of both securities law and accounting rules, it would likely be quite difficult for many lawyers or accountants to develop sufficient expertise in a foreign securities regulatory regime to be able to compete for business with professionals indigenous to the jurisdiction. Lawyers might in addition have to navigate whatever market-restricting professional certification requirements might apply to the practice of law in any particular foreign jurisdiction. Rather than take up these burdens, lawyers and accountants in price-setting jurisdictions are more likely to support the status quo and oppose issuer choice.

Lawyers and accountants might instead diversify their human capital internationally by forming partnerships to pool different types of legal

204. For a discussion of the costs of employing these armies of corporate disclosure professionals, see PHILLIPS \& ZECHER, supra note 187, at 44. 
expertise. Just as a diversified investment portfolio enables investors to eliminate the effects of unsystematic risk, diverse human capital assets within a well-diversified law firm or accounting firm enable the firm, as a whole, to profit despite downturns in particular practice areas at particular times. Profits may be generated by different partners at different times. Over the long run, the peeks and troughs of any given partner's practice activity and profit production are smoothed out via the profit-sharing arrangements of the firm.

Firms can diversify not only across practice areas, of course, but also across countries, so that as economic conditions and revenues change within countries, or as legal or accounting work migrates across borders, an internationally diversified firm is able to smooth out country-based peeks and troughs just as it does for practice areas. At least theoretically, an internationally diversified firm would be indifferent as to which jurisdiction's securities laws applied to particular transactions, since it would have expertise in the law of all important jurisdictions. It would be indifferent as between issuer choice and regulatory price discrimination, except to the extent either would generate more securities work on a global basis.

This possibility of international diversification, however, may not significantly alter the territorial quality of individual lawyers' and accountants' expertise and economic interests. Even in international alliances, firms typically dole out profits based roughly on who is responsible for their creation. That is, each partner eats what she kills. While all members may share in the firm's overall good fortune, they do not typically share equally. The partners responsible for more profitshowever "responsible" is defined within each firm-are usually more equal than others. ${ }^{205}$ In terms of issuer choice proposals, this means that despite being a member of a diversified international firm, a U.S. securities lawyer or accountant will still prefer to maximize the amount of securities work that applies U.S. rules. She would rather do the work and generate the profits than have her partner in another jurisdiction do it.

Finally, depending on how enforcement is structured under an issuer choice regime, securities litigators might possibly see an increased demand for their services. Proponents of issuer choice understandably have not reached consensus as to the appropriate choice of forum for enforcement of the substantive rules chosen by any issuer. ${ }^{206}$ If the

205. Cf. George Orwell, Animal Farm 133 (Penguin Books 1996) (1946) (“All animals are equal. But some animals are more equal than others.”). See generally David B. Wilkins \& G. Mitu Gulati, Why Are There So Few Black Lawyers in Corporate Law Firms? An Institutional Analysis, 84 CAL. L. REV. 493, 535-36 (1996) (discussing competitive nature of law partnerships).

206. See infra notes 239-42. 
issuer's home country were to become the standard venue for enforcement under an issuer choice regime, then it is at least conceivable that U.S. securities litigators could have as much or more work under issuer choice. Suppose issuer choice proponents are correct that free choice would unleash a torrent of heretofore suppressed demand for capital by issuers and demand for securities by investors. ${ }^{207}$ Under this view, issuer choice remedies a regulatory mispricing and eliminates deadweight losses from this mispricing. If the issuer's home country is where private litigation is to be brought, and if U.S. issuers issue more securities worldwide under issuer choice than under the current mandatory U.S. regime, then it is at least conceivable that U.S. securities litigators might end up with more work. Even if U.S. lawyers needed to rely on foreign experts regarding the substantive law of the firm-selected regime, presumably they would still retain a competitive edge in litigating cases in U.S. courts and would be the principal lawyers in those cases. This scenario further assumes, of course, that U.S. issuers would select regimes with nontrivial regulation and that effective private remedies would survive in an issuer choice system. In addition, international arbitration may emerge as a popular method of resolving international securities disputes under an issuer choice regime. ${ }^{208}$ If so, U.S. lawyers may be particularly well-suited to compete for retentions.

On the other hand, these various possible benefits to U.S. lawyers under issuer choice are quite speculative. Lawyers being risk averse in terms of their financial interests, we can expect that in general, they would prefer the bird in the hand-steady augmentation of their fortunes through regulatory price discrimination - to the indeterminate number of birds they might enjoy under issuer choice.

Lawyers and accountants are likely to constitute well-organized and well-financed interest groups. Their undiversified human capital and high per capita economic stakes in continued and expanding application of U.S. securities law suggests that they would offer strong opposition to issuer choice. ${ }^{209}$

207. See Choi \& Guzman, supra note 11, at 916-17; Romano, Empowering Investors, supra note 10, at 2362-64.

208. See Romano, Need for Competition, supra note 10, at 409.

209. Cf. Jonathan R. Macey \& Geoffrey P. Miller, Toward an Interest-Group Theory of Delaware Corporate Law, 65 Tex. L. REV. 469, 498-509 (1987) (describing self-interested role of Delaware corporate bar in influencing course of Delaware corporate law). 


\section{EXCHANGES AND SECURITIES FIRMS}

In contrast to securities lawyers, the fortunes of exchanges and securities firms are tied to the volume of securities offered and traded in the national markets in which they operate, without any necessary connection to applicable law. ${ }^{210}$ To the extent that territorial regulations deter securities activity within a given jurisdiction, exchanges and securities firms would favor reducing those regulatory hurdles. ${ }^{211}$ According to issuer choice proponents, offering issuers a choice of regulatory regimes less stringent and costly than the U.S. regime would almost certainly increase securities activity in the United States in the long run. Moreover, in a world of private choice, according to issuer choice advocates, this desire of securities industry interests to maximize the local volume of securities activity acts as a positive influence on national regulators. Regulators' desire to benefit their important constituents in the industry would spur them to propose regulation that issuers want, since issuers would likely issue securities in the jurisdiction whose regulation they select. ${ }^{212}$

That securities industry interests are promoted through deregulatory reforms that increase local volume, however, does not necessarily mean the industry would favor issuer choice. All sorts of regulatory changes could spur an increase in local volume. Regulatory price discrimination, for instance, does just that. Perhaps recognizing this, the NYSE actively lobbied the SEC to lower certain regulatory requirements for foreign issuers in the United States, ${ }^{213}$ efforts that were rewarded with some of the special rules for foreign issuers that exemplify the SEC's regulatory price discrimination strategy. ${ }^{214}$ The NYSE continues to lobby for relaxed accounting reconciliation requirements for certain categories of foreign issuers. James Cochrane, senior vice president and chief economist for the NYSE, has stated that exempting world-class foreign issuers from U.S. GAAP reconciliation is the NYSE's "number one priority." 215 In

210. As with law firms, exchanges and securities firms may diversify across borders. See Licht, supra note 167, at 592 (discussing recent stock exchange mergers and alliances). With exchanges, because international alliances are a recent development, it is difficult to tell the extent to which exchanges may lose their national character.

211. See James A. Fanto \& Roberta S. Karmel, A Report on the Attitudes of Foreign Companies Regarding A U.S. Listing 5 (NYSE Working Paper No. 97-101, 1997); Choi \& Guzman, supra note 87, at 1874; Fox, Political Economy, supra note 19, at 770.

212. See supra note 85 and accompanying text.

213. Licht, supra note 167, at 597.

214. See supra notes 148-63 and accompanying text.

215. See James L. Cochrane, Are U.S. Regulatory Requirements for Foreign Firms Appropriate?, 17 FordHAM INT'L L.J. S58, S61 (1994). 
addition, while NYSE rules contain certain corporate governance requirements for listed companies, foreign issuers may readily obtain exemptions from these rules. ${ }^{216}$ Similar exemptions are available under the listing rules of the American Stock Exchange and the NASDAQ. The SEC, recognizing the competitive interests of the exchanges in encouraging foreign listings, ${ }^{217}$ acquiesced in this approach. ${ }^{218}$

Critics of the SEC are also quick to point out the well-organized securities industry interests that benefit from the SEC's mandatory disclosure system and other policies. Lawyers and accountants get paid to produce disclosure documents, and securities analysts, portfolio managers, and other securities professionals get the benefit of this publicly disclosed information for free, information they find quite useful but would otherwise have to pay for. ${ }^{219}$ Industry professionals may also be the ultimate beneficiaries of SEC rules against insider trading, since those rules eliminate from the market the only potential traders with better information than industry professionals. ${ }^{220}$

216. See NYSE, New York Stock Exchange Listed Company Manual § 103.00 (1999).

217. The relaxation of requirements applicable to foreign issuers was ... an

SEC response to the needs of the U.S. stock exchanges and their investment banking members to develop a U.S. market for foreign securities. Specifically, they argued that differences between the corporate governance practices of foreign issuers and the corporate governance requirements of the U.S. exchanges would unduly inhibit those companies from listing on U.S. exchanges. Accordingly, the SEC was convinced that the special treatment of foreign issuers was warranted.

Special Study on Market Structure, Listing Standards and Corporate Governance, 57 Bus. LAW. 1487, 1514-15 (2002).

218. Self-Regulatory Organizations; Order Approving Proposed Rule Changes by the American Stock Exchange, Inc. and New York Stock Exchange, Inc. to Amend the Exchanges' Listing Standards for Foreign Companies, Exchange Act Rel. No. 24,634, 52 Fed. Reg. 24,230 (June 29, 1987).

219. See PhILliPS \& ZECHER, supra note 187, at 22-23. One report found securities analysts to be the group most reliant on mandatory filings, as $77.8 \%$ of sell-side and $91.3 \%$ of buy-side analysts reported the Form $10-\mathrm{K}$ was vital to them. See id. at 37 (citing U.S. Congress, House Comm. on Interstate and Foreign Commerce, Report of the Advisory Committee on Corporate Disclosure to the Securities and Exchange Commission, 95th Cong., Comm. Print 95-29 (Nov. 3, 1977), at 62).

220. See David D. Haddock \& Jonathan R. Macey, Regulation on Demand: A Private Interest Model, with an Application to Insider Trading Regulation, 30 J.L. \& ECON. 311 (1987). It is unclear to what extent the recently promulgated Regulation FD will affect the benefits to industry of insider trading prohibitions. "FD" stands "fair disclosure," and among other things, Regulation FD prohibits issuers from making selective disclosure of material nonpublic information See Selective Disclosure and Insider Trading, Release No. 33-7881, Release No. 34-43154, 73 SEC Docket (CCH), at 3 (Aug. 15, 2000). 
Given their stakes in the status quo, and the fact that the SEC's current regulatory price discrimination strategy will increase the volume of local securities activity, industry interests in the United States would likely be reluctant to reject the benefits they currently enjoy in favor of issuer choice, a reform with uncertain impact on their rents. Private institutional arrangements have grown up around the SEC's mandatory disclosure system. As with lawyers and accountants, securities professionals - investment bankers, brokers, analysts, and others-have human and institutional capital invested in existing practices. These practices likely generate increasing returns in the current environment, while switching to issuer choice may impose high start-up costs before comparable benefits were realized, if ever.

Institutions and policies may encourage individuals and organizations to invest in specialized skills, deepen relationships with other individuals and organizations, and develop particular political and social identities. These activities increase the attractiveness of existing institutional arrangements relative to hypothetical alternatives. As social actors make commitments based on existing institutions and policies, their cost of exit from established arrangements generally rises dramatically. ${ }^{221}$

Law reform that would drastically diminish the value of existing arrangements or render them obsolete will not likely garner the support of exchanges or securities firms. ${ }^{222}$ As between regulatory price discrimination and issuer choice, exchanges and securities firms in the United States will likely prefer the former.

\section{ISSUERS AND INVESTORS}

In something of an apparent irony, it appears that "corporate America"-issuers and institutional investors, who are supposed direct beneficiaries of issuer choice-implicitly reject it. John Coates notes that corporate America has instead supported harmonized regulation, both nationally and internationally, a course in exactly the opposite direction

221. Pierson, supra note 195, at 259.

222. The prospects for substantial cost-reducing modification in our corporate disclosure system are . . . slim when viewed from the perspective of the economics of regulation. Two relatively small, well-organized groups have strong and understandable interests in seeing that the SEC corporate system is preserved and expanded, namely, professionals who produce the disclosure documents and who receive them free.

PHILLIPS \& ZECHER, supra note 187, at 51. 
from issuer choice. ${ }^{223}$ On the national level, Coates points out, businesses supported expanded federal securities law preemption of state disclosure rules. ${ }^{224}$ They supported further centralization of federal securities law jurisdiction in response to the perceived circumvention of federal limitations on private securities suits via state court suits. ${ }^{225}$ On the international level, U.S. industries support international harmonization of accounting standards, and not diversity. ${ }^{226}$ Coates suggests this push for harmonization and failure to embrace issuer choice show that issuer choice proposals lack merit. ${ }^{227}$

A more nuanced explanation may also be available. The behavior of corporate America may not necessarily be inconsistent with the claims of issuer choice proponents as to the beneficent effects of such a system. Moreover, at least on the domestic level, issuers' support for federalization of securities law may not evidence a distaste for regulatory competition among states-which was never among the choices available-as much as distaste for the burden of complying with multiple standards. Complying with one mandatory set of rules is easier and cheaper than complying with fifty-one mandatory sets of rules. But this is not to say that issuers would not prefer, if permitted, to choose just one set of rules that would apply nationwide.

However, the timing of the realization of these claimed benefits may matter, as they do for politicians. ${ }^{228}$ For risk averse firm managers with short time horizons, the move to an issuer choice system may simply be too disruptive in the short term. Switching costs may be substantial. ${ }^{229}$ Short-term earnings performance drives stock prices and affects managers' decision making. Managers may not relish unpredictable short-term perturbations in stock prices caused by wholesale changes in the securities regulatory structure. Managers understand the current rules. They and their professional advisers understand how to operate under them. Analysts and institutional investors understand how to price securities under the current regulatory structures. By contrast, even if issuer choice would lead ultimately to lower capital costs, markets and market professionals would require some time to adjust to such a radical

223. Coates, supra note 137, at 538-39.

224. Id. at 538 (discussing National Securities Markets Improvement Act of 1996).

225. Id. (discussing Securities Litigation Uniform Standards Act of 1998).

226. Id. at 539.

227. Id. at 542.

228. See supra notes 195-99 and accompanying text.

229. "[T]he lack of corporate demand for devolution[ is] not surprising in a pathdependent world where any change requires costly adjustments and the loss of sunk capital investments by some participants." William J. Carney, Jurisdictional Choice in Securities Regulation, 41 VA. J. INT’L L. 717, 720-21 (2001). 
change. How markets would behave during this transition period would be difficult to predict. The sheer uncertainty may deter managers and investors from supporting such a change. In addition, managers in high regulation jurisdictions like the United States may fear a negative signaling effect from opting out of U.S. regulation. Finally, not only would managers have to worry about the price effect of issuer choice on their own securities in absolute terms, but they would also have to be concerned about the relative impact of this change on their competitors' capital raising activities. ${ }^{230}$ For all these reasons, risk averse managers with short time horizons may simply not wish to undertake to manage the transition from one equilibrium to another, even if the new equilibrium is ultimately more advantageous once achieved. ${ }^{231}$

Regardless of whether the current position of corporate America undercuts the supposed longer-term benefits of issuer choice, it certainly calls into question the near-term political feasibility of issuer choice proposals. On the other hand, U.S. issuers also oppose regulatory price discrimination, which forces them to pay higher "prices" than their foreign counterparts in terms of more stringent regulatory requirements. Their push for harmonization is consistent with this stance. It may be that for U.S. issuers, harmonization represents the most fruitful short-term strategy to raise capital costs for their foreign rivals.

U.S. issuer opposition to regulatory price discrimination, however, should not be overstated. Corporations have in the past organized effectively to affect securities regulatory policy, through such collective organizations as the Business Roundtable and the like. ${ }^{232}$ However, there is some reason to believe that the differential regulatory burdens as between domestic and foreign issuers would have to be substantial, and the number of foreign issuers benefiting from disparate regulation would have to increase, before domestic issuers in general would be willing to

230. Especially with respect to foreign rivals who are not already raising capital in the United States, U.S. issuers currently enjoy a natural advantage because of their mastery of the system. As issuer choice advocates and others have suggested, the regulatory and other intricacies of capital raising in the United States may inhibit some foreign entrants. A move to issuer choice, however, would very likely erode this natural advantage that U.S. issuers currently enjoy.

231. In a related context, Romano has argued that risk averse firm managers may prefer a maximin strategy with respect to law reform, preferring the status quo to unpredictability in corporate law. See Roberta Romano, The State Competition Debate in Corporate Law, 8 CARDOZO L. REV. 709, 722 (1987) (explaining why firm managers may prefer Delaware's constitutional provision requiring a two-thirds supermajority for amendments to its corporation law).

232. See Coates, supra note 137, at 540-42 (discussing role of industry representatives in overcoming collective action problems to enact major federal securities law reform). 
commit resources to political action. The existence of differential burdens of mandatory disclosure, for example, is not likely to be the first thing on a CEO's mind. U.S. firms have adapted to their disclosure burdens, the costs of which are buried in their legal and accounting bills, and which can to some extent be passed on to customers, suppliers, employees, and investors.

Moreover, domestic firms will vary in the extent to which they feel any effects from regulatory price discrimination. A given domestic firm will associate differential regulatory burdens with a loss of competitiveness with foreign rivals only if its foreign rivals undertake substantial capital raising in U.S. public markets. Without numerous specific incidents of this lowering of foreign rivals' costs from regulatory price discrimination, it is not likely to be an issue of general interest across corporate America. Merritt Fox has noted, for example, that large U.S. issuers have voiced almost no objection to a proposal backed by the NYSE to relieve foreign issuers from having to reconcile their books to U.S. GAAP. ${ }^{233}$ U.S. firms are far more likely to focus on product competition with their foreign rivals, as opposed to financing competition. Lobbying for tariff protection against foreign products, for example, is common. Lobbying to bar or impede "imports" of foreign securities seems less likely.

\section{The Calculus of International Consent}

In addition to the improbability of interest group alignments supporting issuer choice in regulatory price-setting jurisdictions, international issuer choice agreements will be difficult to achieve. Despite its offhand treatment by issuer choice advocates, the choice of law cooperation that would be necessary to implement private choice is far from trivial or easily accomplished. Besides the prospect of domestic interest group opposition in regulatory price-setting jurisdictions, the mechanics of international policy coordination suggest further hurdles that would have to be overcome in order for international issuer choice to emerge.

\section{INTERNATIONAL COALITIONS AND DISPERSED VETO POWER}

The global legal environment is "tilted against effective regulation." ${ }^{234}$ In the domestic context, collective action can effect

233. See Fox, Political Economy, supra note 19, at 765 \& n.148.

234. Jonathan Baert Wiener, On the Political Economy of Global Environmental Regulation, 87 GEO. L.J. 749, 761 (1999). 
binding policy change on dissenters through the assembling of a majority coalition. However, assembly of the requisite coalitions in the international context is much more difficult, especially in the absence of some pre-existing transnational institutional structure. ${ }^{235}$

Among anarchic nations, ${ }^{236}$ the voting rule in international policymaking is a sort of unanimity requirement. Each state sought to be bound by treaty must assent to it. Objecting states are not bound. Therefore, overcoming collective action problems among states may be quite a formidable task. Each state must either perceive itself a net winner by participating, or transfer payments must be arranged. This means that within each participating state, a majority coalition must exist that stands to benefit from participation.

In effect, the power to veto international agreements is more widely available among interest groups than with domestic legislation. The existence of an opposing majority coalition in any prospective participating state will cause that state's rejection of the arrangement. Even strategic delay by an opposing minority in one nation might scuttle an agreement if majority coalitions in important states cannot be held together long enough for an agreement to be reached. Given this context, the opposition of the regulatory bureaucracy in any important state could be fatal to the achievement of a widely accepted issuer choice treaty.

Ideally, for an international issuer choice regime, the United States and other regulatory price-setting jurisdictions would participate. The existence of a blocking coalition within any of these jurisdictions would damage the prospects for achieving an issuer choice agreement, and would diminish the benefits of any agreement achieved.

\section{COMPLEXITY OF AN INTERNATIONAL ISSUER CHOICE TREATY}

Even aside from the private interests in particular states that would oppose issuer choice, implementation of the requisite choice of law cooperation may be impeded by technical concerns. The terms of an issuer choice treaty would hardly be straightforward. Uncertainty as to the particular operation of securities laws under an international issuer choice arrangement will tend to hamper treaty efforts.

235. See Frederick Tung, Is International Bankruptcy Possible?, 23 МicH. J. INT'L L. 31, 90 (2001) (discussing role of international institutions in facilitating cooperation).

236. "Nations dwell in perpetual anarchy, for no central authority imposes limits on the pursuit of sovereign interests." Kenneth A. Oye, Explaining Cooperation Under Anarchy: Hypotheses and Strategies, 38 WoRLD PoL. 1 (1985). 
Choice of law rules are notoriously indeterminate, ${ }^{237}$ and international issuer choice agreements may be difficult to specify with particularity ex ante. The point of any issuer choice arrangement is to enable private parties to displace local regulation with regulation of their own choosing. However, transplanting a regulatory regime from its original context to another jurisdiction is unlikely to be a neat and tidy affair. Especially in industrial countries, securities regulation is fairly complex, depending not only on intricate rules but also on numerous institutions for its implementation. Not only regulators, but courts, stock exchanges, and self-regulating organizations all play a role. In the United States, each of these institutions may play a role in ex ante supervision as well as ex post enforcement. Importing a securities regulatory regime by contract or treaty will not be a straightforward enterprise. A simple choice of law rule requiring respect for private choice of substantive law does not by itself replicate the institutional arrangements that may be critical to a regulatory regime. ${ }^{238}$

Any treaty committing nations to private choice would likely rely on imprecise standards and ex post discretion of judges or regulators. Regulators and their important constituents might therefore have difficulty anticipating the consequences of a private choice arrangement, and firms might be unable to predict the effect of their private choices. This indeterminacy could make interest groups reluctant to support such agreements in the first place.

Enforcement raises perhaps the most significant concern. Enforcement across jurisdictions, if workable at all, is likely to be difficult to specify and difficult to police. Each nation is likely to rely on particular legal institutions to enforce its laws, and some may be unique to its securities regulation. An arrangement for private choice would require some consideration for whether and which enforcement institutions "travel" with the choice of substantive law.

The trade offs in terms of regime-selected institutions versus homecountry enforcement have been aired. Romano and Choi and Guzman argue that regime-selected regulators and institutions are best situated to enforce, since they will generally be experts on the nuances of the legal

237. See Michael Whincop, The Recognition Scene: Game Theoretic Issues in the Recognition of Foreign Judgments, 23 MelbouRne U. L. ReV. 416, 427-28 (1999) (identifying indeterminacy of choice of law rules as reason for absence of choice of law requirement for judgment recognition).

238. "[T]he institutions necessary for effective securities regulation are not easily transplantable. The primary problem . . . is local enforcement and local culture in the receiving country, for even world-class laws need to be understood by those subject to them and enforced by state institutions." Licht, supra note 129, at 679; see also Cox, supra note 20, at 1240 (discussing crucial interpretive role of SEC staff). 
rules to be applied. ${ }^{239}$ Centralizing litigation and other enforcement activity in this way enables consistent development of the regime-selected law, as compared to other approaches that involve interpretation by various nations' courts. Finally, the benefits of regulatory competition are maximized when the legislative and judicial functions come under the same sovereign. When authority over outcomes is split between the rule givers of one state and the judiciary of another, the rule-giving state is impeded in its ability to respond to consumer demand. It cannot guarantee that its regulatory product will be sufficiently nuanced to display all the features consumers want. ${ }^{240}$

On the other hand, as Steven Walt notes, the conduct to be regulated, and which would form the basis for any lawsuit, is most likely to occur in the issuer's home country. Local institutions in the home country are likely to be more familiar with local business practices. Therefore, the home country may be the most convenient venue for regulating conduct, gathering evidence, and realizing on the firm's assets. ${ }^{241}$ According to Walt, being "on the ground" where violative conduct occurs gives homecountry regulators a natural advantage over their foreign counterparts. It may be easier for home-country regulators to master the various substantive laws they must enforce under issuer choice than it would be for foreign regulators to operate in the local legal environment. ${ }^{242}$

Conceptually, it would seem that as a matter of consistency with the premises of the brief for private choice, regime-selected institutions have one other significant factor recommending them. Enforcement must be seen as an integral aspect to the product itself, and if states are meant to be competing suppliers in an international market for regulatory products, then only the supplier has the right incentives to "service" the product properly. Not only may the issuer's home-country institutions lack sufficient incentive or sufficient administrative capacity to enforce the regime-selected rules faithfully, but they may have incentive to do just the opposite. Home-country enforcers may have incentive to sabotage competitors' products by tinkering with enforcement. It is not difficult to imagine situations in which home-country enforcers may be able to favor local interests in particular cases, while at the same time creating

239. See Choi \& Guzman, supra note 11, at 931 (recommending regime jurisdiction as default rule); Romano, Need for Competition, supra note 10, at 407 (same).

240. See Romano, Need for Competition, supra note 10, at 407 \& n.46.

241. See Steven Walt, Introduction: Privatization and Its Prospects, 41 VA. J. INT’L L. 517, 527 (2001); see also Choi \& Guzman, supra note 11, at 928.

242. See Walt, supra note 241. In addition, as Jim Cox has noted, it may be difficult to structure appropriate incentives to encourage foreign regulators' vigorous enforcement of their own laws in jurisdictions where they have no political constituents. See Cox, supra note 20, at 1240-41. 
confusion over application of another state's rules. Such an enforcement strategy would serve to discourage local firms from choosing non-local rules, advantaging the local regulatory product in the local market.

This enforcement morass is only the most immediate question mark for issuer choice arrangements. The complications of enforcement suggest that treaties facilitating the private mixing and matching of regulatory regimes are not likely to be simple. An unadorned edict to honor firms' private choice will not be sufficient. Negotiating agreement on these issues among multiple states-each state with its own commercial and corporate law, culture and history, as to which any issuer choice regime would have to be integrated-is likely to be quite difficult. ${ }^{243}$

The complexity of these issues portends not merely difficulty in treaty drafting, but indeterminacy as to outcomes. Even if law makers and their important interest groups supported private choice in theory, they might have difficulty predicting how such an arrangement would work, what national commitments would entail, and how private benefits would be distributed. These indeterminacies might discourage the establishment of such arrangements at the outset.

Issuer choice advocates have failed to grapple with these difficulties. For example, while Choi and Guzman express doubt that states could cooperate successfully on harmonizing substantive rules, ${ }^{244}$ they fail to acknowledge that an international regime of issuer choice would also

243. "A choice of law treaty is not unprecedented, although the characteristics of different investors and default rules might complicate the product.” Walt, supra note 241, at 525 .

244. They cite insider trading rules as an example:

[E]fforts on the part of countries to construct workable international cooperation in securities regulation, although fine in theory, are most likely to fail. In theory, countries may design efficient securities regulations through international cooperation that would be enforced globally. Parties engaging in securities fraud, for example, would find it difficult to escape enforcement under a perfect global regulatory regime. In practice, of course, the existing global regulatory regime is far from perfect. Although the SEC has met with some success in gaining cooperation from other countries regarding insider trading laws, international cooperation remains limited. Despite the facial success of the SEC's efforts, agreements between countries are often difficult and time consuming to obtain. Moreover, once agreements are signed, countries must expend resources monitoring compliance. For example, initial evidence on the insider trading laws instituted in Japan and Switzerland demonstrate less than vigorous enforcement. Over time, national regulatory bodies may take over the agreement, adding provisions and increasing the complexity of the regime to enhance the importance of the regulatory agencies.

Choi \& Guzman, supra note 11, at 915-16 (emphasis added) (citations omitted). 
require politically significant cooperation among states, perhaps even more politically significant than substantive harmonization.

\section{Alternative Ending: Harmonization?}

The preceding discussion predicts a failure of supply in terms of choice of law rules that would be necessary to effect issuer choice. The same discussion further serves as a roadmap to more likely political outcomes.

The regulatory price discrimination strategy that the SEC to some extent has already pursued may generate stronger opposition from U.S. issuers over time. The costs to domestic issuers of differential regulatory burdens as compared to foreign issuers may at some point become sufficiently large and widespread that collective action for U.S. issuers will make sense. Bill Carney has predicted, for example, that pressure from the exchanges will lead the SEC to accept international disclosure standards for foreign issuers. "And once foreign issuers can avoid U.S. GAAP and some other burdens of U.S. regulation, can parity for U.S. issuers be far behind?”245

Parity for U.S. issuers - if it does come-may take the form of harmonized international standards. It is not likely to lead to issuer choice. A prediction of harmonization, moreover, more closely comports with the public choice assumptions of issuer choice proponents. Harmonization and the ongoing international negotiations required to implement it preserve and augment regulators' authority, prestige, and budget. $^{246}$ International negotiations are likely to be complicated and technical affairs, placing the SEC and other national regulators at the center of international reform that is to a great extent insulated from political accountability. ${ }^{247}$ Jon Macey cites as one example the SEC's lobbying of other states to adopt and enforce U.S.-style insider trading prohibitions. ${ }^{248} \mathrm{He}$ argues that this harmonization effort was driven by the SEC's desire to maintain its own authority by preventing regulated parties' easy exit to more lax jurisdictions. The SEC has additionally used its position within IOSCO to push for harmonization. ${ }^{249}$

245. Carney, supra note 229, at 723.

246. See Colombatto \& Macey, supra note 59 (characterizing SEC efforts at international coordination of insider trading enforcement as an attempt to preserve its own authority).

247. See Paul Stephan, The Futility of Unification and Harmonization in International Commercial Law, 39 VA. J. INT'L L. 743 (1999) (describing work of international private legislatures).

248. See Colombatto \& Macey; see also supra note 59.

249. See id. at 953; supra Part I.A.2. 
In addition, harmonization may provide important benefits to various U.S. constituencies the SEC has traditionally supported. Harmonization efforts will generally result in international standards lower than existing U.S. standards but higher than those of most other states. Successful harmonization may therefore drive marginal foreign issuers to the United States by raising their costs of issuing outside the United States while lowering their costs of issuing in the United States. The securities industry can therefore be expected to benefit from harmonization.

Local lawyers and accountants would also benefit insofar as the value of their expertise would be preserved. Domestic securities law may change, but it will not be replaced wholesale by foreign law, as under issuer choice. Harmonization may also benefit U.S. issuers insofar as it raises foreign rivals' capital costs-depending on the agreed substantive standards - as compared to the status quo.

In effect, harmonization strikes a politically more acceptable distribution of benefits among interested parties than does issuer choice. The SEC's role in securities regulation is not threatened. Its expertise and that of private securities lawyers and accountants remain relevant. Securities firms retain some of their informational and other advantages, and they and exchanges enjoy increased volume. Issuers get a level playing field with their foreign rivals. This is not to suggest that harmonization will necessarily be easy to achieve across the broad range of securities law issues. But the incentives are right.

\section{CONCLUSION}

Issuer choice proponents have raised novel and interesting arguments favoring regulatory competition in securities law. However, the debate so far is incomplete. Scholars have debated the demand side. They have theorized about the behavior of firms and investors in demanding optimal securities law. However, issuer choice proponents have yet to provide a full account of the supply side. In a competitive setting, it may be that regulators would have incentive to supply optimal rules in order to expand their regulatory purview and benefit favored constituents. However, structuring a competitive setting in the first place will require a special set of choice of law rules to be agreed among states. Regulators will have insufficient incentive to push for such rules, largely for the exact reasons issuer choice advocates cite for their predictions of vigorous competition over substantive rules in the ideal global market for law. If regulators value increasing prestige and scope of their regulatory authority, if they wish to maximize the number of regulated firms within their purview, then they will not readily agree to give up the territorial monopolies they already enjoy. 
Legislative and executive action is possible-and would in all likelihood be required - in order to establish the competitive setting issuer choice advocates envision. However, regulators would be powerful opponents of any international cooperative endeavors that would weaken their regulatory monopolies. Other interest groups exist, but it is doubtful—at least in the United States and probably in other price-setting jurisdictions as well-that any would prefer issuer choice to the regulatory price discrimination that is the status quo. Moreover, the complexities associated with any international issuer choice treaty make credible commitments difficult to obtain.

Political feasibility may seem a harsh metric against which to appraise normative scholarship. After all, knowing the contours of the first best solution is valuable though we may readily concede the difficulty of its implementation. Issuer choice proposals, however, deserve particular scrutiny in this regard because they depend critically on assumptions about bureaucratic behavior in an international setting, but much that is important about that international setting is assumed away. The anarchy of the international setting, so central to the work of scholars in international relations and other disciplines, cannot be so easily set aside. ${ }^{250}$ No global framework for regulatory competition exists. With that factored into the analysis, the assumptions ultimately show the improbability of the issuer choice proposal, ${ }^{251}$ as well as the probability of regulatory price discrimination.

Doubting issuer choice is not to say that securities laws will not adapt because of competitive pressures. Others have made the case that the SEC, for example, is already responsive to the concerns of U.S.

250. Ironically, Choi \& Guzman doubt the promise of other approaches to international coordination on political feasibility grounds. They are skeptical of "normal" reciprocity arrangements-which require an issuer selling securities in a foreign market merely to comply with its domestic regulatory regime. This skepticism arises in part because "countries typically consider such agreements only when the laws of the signatories are extremely similar.” Choi \& Guzman, supra note 11, at 920. In addition, regulators fear investor confusion if securities trading on local markets were subject to various different regulatory regimes. "This concern typically reduces the interest of regulators in reciprocity arrangements, which minimizes the number of such agreements and their impact on regulatory competition.” Id. Presumably, though, these same factors impede the prospects for issuer choice reciprocity at least as much.

251. In a related context, another scholar has observed:

one of the difficulties presented by public-choice-oriented normative scholarship: what is a public choice ... scholar to do, when the audience he is trying to influence, whom he is trying to get to adopt his recommendations, is composed of the same group of people that his own theories suggest are not collectively capable of pursuing the public interest?

Kyle D. Logue, If Taxpayers Can't Be Fooled, Maybe Congress Can: A Public Choice Perspective on the Tax Transition Debate, 67 U. CHI. L. REV. 1507, 1529 (2000). 
issuers and the securities industry. ${ }^{252}$ The competition-driven evolution of national securities laws is already underway. Issuers and investors are mobile now to some extent and will only grow more so over time. However, the sort of mobility envisioned by issuer choice advocates depends on international cooperation over explicit legal rules endorsing exit from regulatory regimes in which too many are too deeply invested. Those legal rules will be in short supply.

252. See Coates, supra note 137, at 553. 